Hobbs, R.W., Huber, B.T., Bogus, K.A., and the Expedition 369 Scientists Proceedings of the International Ocean Discovery Program Volume 369 publications.iodp.org https://doi.org/10.14379/iodp.proc.369.101.2019

\section{Expedition 369 summary ${ }^{1}$}

B.T. Huber, R.W. Hobbs, K.A. Bogus, S.J. Batenburg, H.-J. Brumsack,

R. do Monte Guerra, K.M. Edgar, T. Edvardsen, M.L. Garcia Tejada, D.L. Harry, T. Hasegawa, S.J. Haynes, T. Jiang, M.M. Jones, J. Kuroda, E.Y. Lee, Y.-X. Li, K.G. MacLeod, A. Maritati, M. Martinez, L.K. O'Connor, M.R. Petrizzo, T.M. Quan, C. Richter, L. Riquier, G.T. Tagliaro, C.C. Wainman, D.K. Watkins, L.T. White, E. Wolfgring, and Z. $\mathrm{Xu}^{2}$

Keywords: International Ocean Discovery Program, IODP, JOIDES Resolution, Expedition 369, Site U1512, Site U1513, Site U1514, Site U1515, Site U1516, Hot Cretaceous Greenhouse, oceanic anoxic events, Mentelle Basin, Naturaliste Plateau, Great Australian Bight, Gondwana breakup, Tasman Gateway, Indonesian Gateway, cyclostratigraphy, carbon isotope excursions, Paleocene/Eocene Thermal Maximum, Eocene greenhouse, Miocene, volcanic rifted margin, nonvolcanic rifted margin

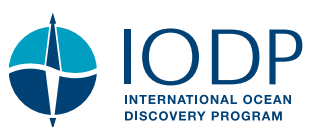

Check for updates

Contents

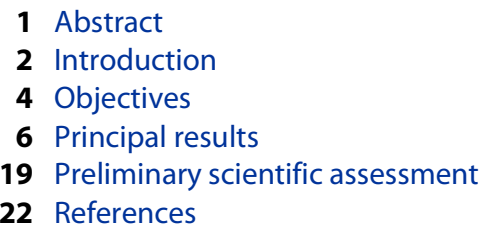

1 Abstract

2 Introduction

4 Objectives

19 Preliminary scientific assessment

22 References

\section{Abstract}

The tectonic and paleoceanographic setting of the Great Australian Bight (GAB) and the Mentelle Basin (adjacent to Naturaliste Plateau) offered an opportunity to investigate Cretaceous and Cenozoic climate change and ocean dynamics during the last phase of breakup among remnant Gondwana continents. Sediment recovered from sites in both regions during International Ocean Discovery Program Expedition 369 will provide a new perspective on Earth's temperature variation at subpolar latitudes $\left(60^{\circ}-62^{\circ} \mathrm{S}\right)$ across the extremes of the mid-Cretaceous hot greenhouse climate and the cooling that followed. Basalts and prebreakup sediments were also recovered and will provide constraints regarding the type and age of the Mentelle Basin basement and processes operating during the break up of Gondwana. The primary goals of the expedition were to

- Investigate the timing and causes for the rise and collapse of the Cretaceous hot greenhouse climate and how this climate mode affected the climate-ocean system and oceanic biota;

- Determine the relative roles of productivity, ocean temperature, and ocean circulation at high southern latitudes during Cretaceous oceanic anoxic events (OAEs);

- Investigate potential source regions for deep-water and intermediate-water masses in the southeast Indian Ocean and how these changed during Gondwana breakup;

- Characterize how oceanographic conditions at the Mentelle Basin changed during the Cenozoic opening of the Tasman Gateway and restriction of the Indonesian Gateway; and
- Resolve questions on the volcanic and sedimentary origins of the Australo-Antarctic Gulf and Mentelle Basin and provide stratigraphic control on the age and nature of the prebreakup successions.

Hole U1512A in the GAB recovered a $691 \mathrm{~m}$ thick sequence of black claystone ranging from the lower Turonian to the lower Campanian. Age control is primarily based on calcareous nannofossils, but the presence of other microfossil groups provided consistent low-resolution control. Despite the lithologic uniformity, long- and short-term variations in natural gamma radiation and magnetic susceptibility show cyclic alternations that suggest an orbital control of sediment deposition, which will be useful for developing an astrochronology for the sequence.

Sites U1513, U1514, U1515, and U1516 were drilled in water depths between 850 and $3900 \mathrm{~m}$ in the Mentelle Basin and penetrated 774, 517, 517, and 542 meters below seafloor, respectively. Under a thin layer of Pleistocene to upper Miocene sediment, Site U1513 cored a succession of Cretaceous units from the Campanian to the Valanginian, as well as a succession of basalts. Site U1514 sampled an expanded Pleistocene to Eocene sequence and terminated in the upper Albian. The Cenomanian to Turonian interval at Site U1514 is represented by deformed sedimentary rocks that probably represent a detachment zone. Site U1515 is located on the west Australian margin at $850 \mathrm{~m}$ water depth and was the most challenging site to core because much of the upper $350 \mathrm{~m}$ was either chert or poorly consolidated sand. However, the prebreakup

\footnotetext{
${ }^{1}$ Huber, B.T., Hobbs, R.W., Bogus, K.A., Batenburg, S.J., Brumsack, H.-J., do Monte Guerra, R., Edgar, K.M., Edvardsen, T., Garcia Tejada, M.L., Harry, D.L., Hasegawa, T., Haynes, S.J., Jiang, T., Jones, M.M., Kuroda, J., Lee, E.Y., Li, Y.-X., MacLeod, K.G., Maritati, A., Martinez, M., O'Connor, L.K., Petrizzo, M.R., Quan, T.M., Richter, C., Riquier, L., Tagliaro, G.T., Wainman, C.C., Watkins, D.K., White, L.T., Wolfgring, E., Xu, Z., 2019. Expedition 369 summary. In Hobbs, R.W., Huber, B.T., Bogus, K.A., and the Expedition 369 Scientists, Australia Cretaceous Climate and Tectonics. Proceedings of the International Ocean Discovery Program, 369: College Station, TX (International Ocean Discovery Program). https://doi.org/10.14379/iodp.proc.369.101.2019

2 Expedition 369 Scientists' affiliations.

MS 369-101: Published 25 May 2019

This work is distributed under the Creative Commons Attribution 4.0 International (CC BY 4.0) license. (cc) BY
} 
Jurassic(?) sediments interpreted from the seismic profiles were successfully recovered. Site U1516 cored an expanded Pleistocene, Neogene, and Paleogene section and recovered a complete Cenomanian/Turonian boundary interval containing five layers with high organic carbon content.

Study of the well-preserved calcareous microfossil assemblages from different paleodepths will enable generation of paleotemperature and biotic records that span the rise and collapse of the Cretaceous hot greenhouse (including OAEs $1 \mathrm{~d}$ and 2), providing insight to resultant changes in deep-water and surface water circulation that can be used to test predictions from earth system models. Measurements of paleotemperature proxies and other data will reveal the timing, magnitude, and duration of peak hothouse conditions and any cold snaps that could have allowed growth of a polar ice sheet. The sites contain a record of the mid-Eocene to early Oligocene opening of the Tasman Gateway and the Miocene to Pliocene restriction of the Indonesian Gateway; both passages have important effects on global oceanography and climate. Advancing understanding of the paleoceanographic changes in a regional context will provide a global test on models of Cenomanian to Turonian oceanographic and climatic evolution related both to extreme Turonian warmth and the evolution of OAE 2.

The Early Cretaceous volcanic rocks and underlying Jurassic(?) sediments cored in different parts of the Mentelle Basin provide information on the timing of different stages of the Gondwana breakup. The recovered cores provide sufficient new age constraints to underpin a reevaluation of the basin-wide seismic stratigraphy and tectonic models for the region.

\section{Introduction}

Understanding the mechanisms, feedbacks, and temporal relationships that link climate dynamics of polar regions and the tropics is of fundamental importance for reconstructing past climate changes, including rapid shifts, and hence improving predictions in the future. High-resolution stratigraphic records from strategic locations around the globe, especially from the high-latitude oceans, are essential to achieve this broad goal. Within this context, past periods of extreme warmth, such as the Cretaceous hot greenhouse and the initial Eocene thermal maximum, have attracted increasing research interest over recent years, which has resulted in often spectacular and sometimes contradictory insights into the mechanisms of natural short-term changes in climate, biogeochemical cycling, and ocean oxygenation. International Ocean Discovery Program (IODP) Expedition 369 targeted these fundamental objectives with the specific goals of providing samples from high-latitude Southern Ocean sites with expanded late Mesozoic and Cenozoic sections and improving constraints on the tectonic history of the region.

Expedition 369 recovered sediments from the Great Australian Bight (GAB) and Mentelle Basin that will provide new insights to the evolution of Southern Hemisphere, high-latitude Cretaceous climates. The high paleolatitude $\left(60^{\circ}-62^{\circ} \mathrm{S}\right)$ location of the sites (Figure F1) is especially important for global climatic studies because of the enhanced sensitivity to changes in ocean temperature. Study of the recovered sections will enable generation of high-resolution stratigraphic records across the rise and collapse of the Cretaceous hot greenhouse climate and concomitant changes in Earth's latitudinal thermal gradients and deep ocean circulation that continued through the Cenozoic. The well-resolved age framework of the pelagic carbonate sequences will enable more precise correla-
Figure F1. Late Cenomanian (bottom) and middle Eocene (top) paleogeographic reconstructions after Hay et al. (1999) with locations of Expedition 369 sites (yellow circles) in the Mentelle Basin (MB; adjacent to Naturaliste Plateau), the GAB, and selected deep-sea sites (DSDP Sites 327 and 511; ODP Sites 689 and 690) at southern high latitudes.
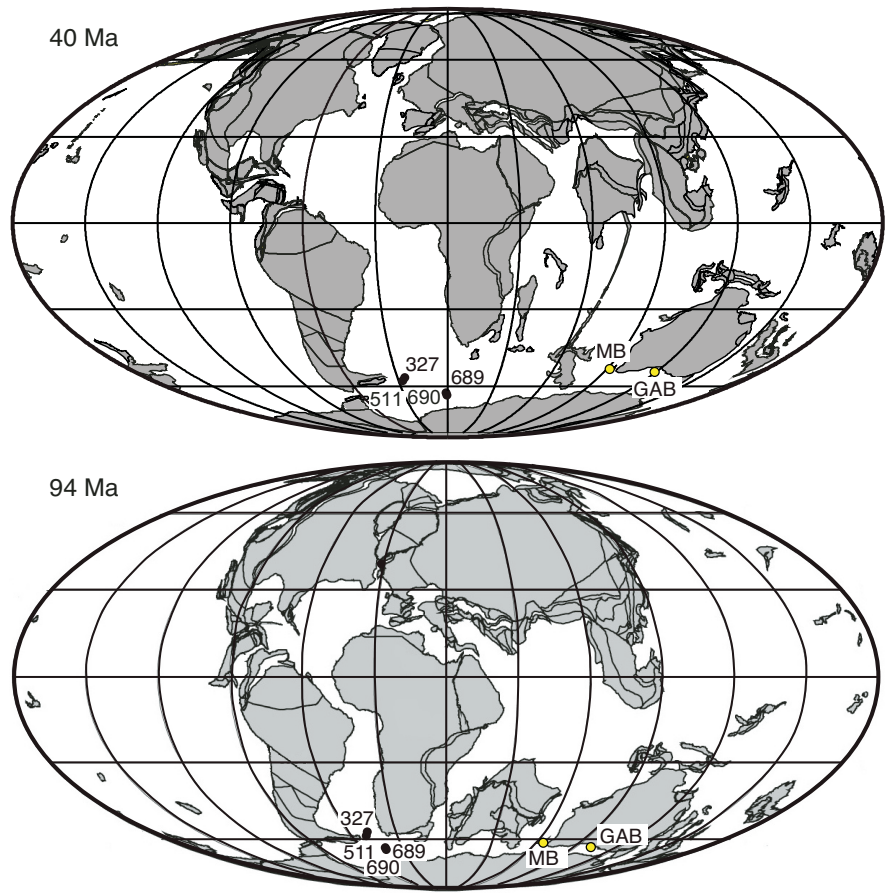

tion between global climatic shifts and tectonic history, especially major volcanic episodes in the region. These aspects are crucial to improve our understanding of Earth's climate system and to inform the scientific modeling community about high-latitude Southern Hemisphere Cretaceous (and possibly older) records in a currently underexplored region.

\section{Background}

\section{Geological setting}

Following the collision of Gondwana with Laurasia at 330-320 $\mathrm{Ma}$, which formed the supercontinent of Pangaea, the breakup of eastern Gondwana commenced during the Jurassic (Veevers, 2006). At this time, the Naturaliste Plateau was located near the junction of the Australian, Antarctic, and Greater India plates (Figure F1) at $60^{\circ}-62^{\circ} \mathrm{S}$. The first stage of breakup occurred in the Early Cretaceous as India separated from Australia. Then later, in the early Eocene, Australia separated from Antarctica.

\section{The Mentelle Basin and rifting of Greater India}

The Mentelle Basin is part of a sequence of basins along the western margin of Australia that formed during the breakup with India and separates the Naturaliste Plateau from Australia (Bradshaw et al., 2003). The basin is the southernmost in a series of en echelon basins from a rifting episode that initiated in northwestern Australia in what is now the Argo Abyssal Plain and southward (Maloney et al., 2011) and is separated from the Perth Basin by the basement high of the Leeuwin Block and the Yallingup Shelf (Figure F2). Despite its water depth (2000-4000 m), the basement under the Mentelle Basin is believed to be continental and to contain Jurassic and possibly older sediments that were deposited in extensional basins. The Naturaliste Plateau is classed as a volcanic margin 
Figure F2. A. Regional context of the Naturaliste Plateau and Mentelle Basin, including location of the major reflection seismic profiles, nearby DSDP sites (red numbers), and Expedition 369 sites (yellow circles). B. Location of Site U1512 (yellow circle) in the GAB, Leg 182 site (white circle), and petroleum exploration wells (black circles).

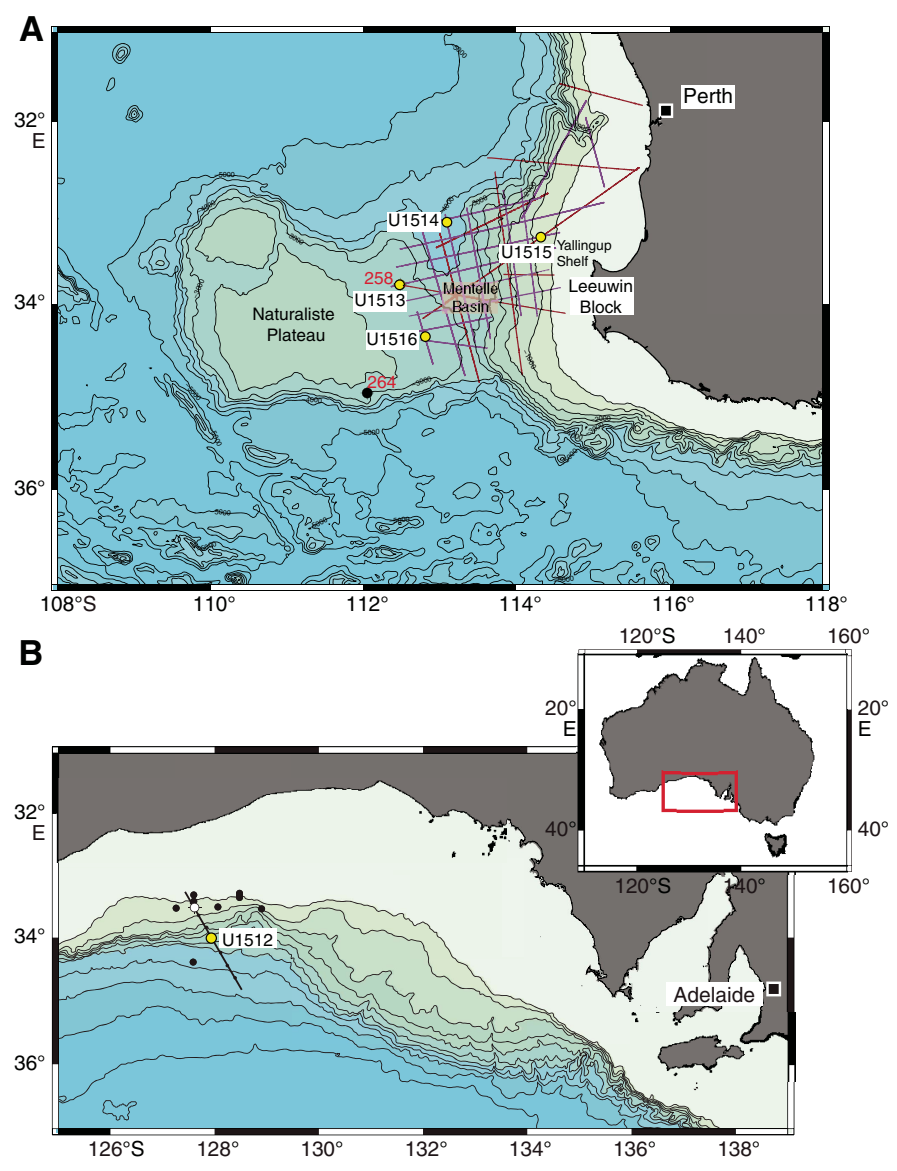

as evidenced by the onshore Bunbury basalt, which recent dating has given an age of 137-130 Ma (Direen et al., 2017). This date is contemporaneous with the final stages of rifting but is older than the basalt found on the Kerguelen Plateau, even though the geochemistry is similar (Olierook et al., 2016). Basalt is widely dredged around the Naturaliste Plateau, and its extent throughout the Mentelle Basin is interpreted from seismic data as a high-amplitude reflection used to denote the top of the Valanginian (Borissova, 2002). The younger sediments were deposited in a thermally subsiding basin and margin. Deep Sea Drilling Project (DSDP) Site 258 previously drilled this postrift section on the western margin of the Mentelle Basin but stopped short of the interpreted basalt horizon.

Seismic data acquired in 2004 and 2009 by Geoscience Australia (tied to Site 258) provided a regional survey to appraise the stratigraphic, structural, and depositional history of the Mentelle Basin (Maloney et al., 2011; Borissova et al., 2010). Relatively young Neogene carbonate oozes unconformably overlie Paleogene deep marine chalk. Occasional, bright reflection events in this sequence are likely caused by thin chert bands. The Paleogene chalk unconformably overlies Cretaceous coccolith-rich chalk that is underlain by Albian/Aptian claystones and a glauconitic sandstone. The unconformity at the base of the ooze and at the top of the glauconitic sandstone can be identified and interpreted from the seismic data; the other boundaries do not create distinct reflections. The glauco- nitic sandstone sequence is floored by a high-amplitude reflection (not sampled at Site 258) interpreted to be caused by Valanginian volcanics. Hence, this horizon coincides with the onset of breakup and separation of Greater India from Australia and a series of subsequent volcanic episodes related to the continuing breakup on the northern and western margins of the Naturaliste Plateau. Prior rifting of the area is recorded by Early Cretaceous, Jurassic, and Permian/Triassic sequences, although the interpretation is somewhat speculative because the sequences lack borehole control.

\section{Opening of the Australo-Antarctic Gulf}

The breakup on the southern margin of Australia is thought to have started in the Cenomanian to Turonian (Direen et al., 2011) and proceeded at a very slow rate. In contrast to the rifting history of Greater India, this margin is believed to have been nonvolcanic. Plate tectonic reconstructions that correspond to the early stages of rifting are poorly constrained and controversial (White et al., 2013). The $\sim 15 \mathrm{~km}$ thick post-Middle Jurassic sedimentary sequence that accumulated in the GAB contains the largest continental margin deltaic sequence deposited during the Late Cretaceous greenhouse period. Accelerated subsidence commencing in the late Albian and continuing through the Cenomanian to Santonian led to the deposition of a thick sequence of marine shales (Totterdell et al., 2000). During the Cretaceous, the GAB was situated at the eastern tip of a partial seaway, the Australo-Antarctic Gulf (AAG), with the Naturaliste Plateau in the open ocean at the western gateway that connected the AAG with the southern Indian Ocean.

An overall transgressive phase of sedimentation in the early Paleogene was followed by the establishment of open-marine carbonate shelf conditions from the early Eocene onward. The AAG eventually widened to create the Southern Ocean, with a switch to rapid spreading after $45 \mathrm{Ma}$ (White et al., 2013). An industry well, Jerboa-1, in the Eyre subbasin on the continental shelf provided a stratigraphic tie along Geoscience Australia seismic Profile s065-06 (Bradshaw et al., 2003).

\section{Opening of the Indian Ocean and Tasman Gateway and closure of the Indonesian Gateway}

After initial rifting, India drifted north-northwest from Australia with strike-slip motion along the Wallaby-Zenith Fracture Zone. This juxtaposed their continental shelves until 120 Ma and isolated the nascent Indian Ocean from global deep-water circulation (Gibbons et al., 2013). Subsequently, the northward drift of Australia through the Cenozoic affected changes in two important ocean gateways to the Indian Ocean: the opening of the Tasman Gateway between Australia and Antarctica in the middle Eocene to early Oligocene and the restriction of the Indonesian Gateway between Australia and Southeast Asia in the Miocene to Pliocene. Both passages have important effects on global oceanography and climate, and the Naturaliste Plateau/Mentelle Basin region is well situated to monitor their opening history and resultant effects on ocean circulation (Figure F3).

The Antarctic Circumpolar Current (ACC) in the Southern Ocean has an important role in present-day overturning circulation and surface heat redistribution (Lumpkin and Speer, 2007). Although there is no significant restriction on the ACC in the modern Tasman Gateway, the Tasman Gateway and Drake Passage both opened during the middle Eocene to Oligocene, and the flow restriction at the Tasman Gateway would have had a significant effect on ocean circulation, especially in the late Eocene to early Oligocene and earlier. During the Paleocene to Eocene, 
Figure F3. Ocean currents in the modern ocean surrounding Australia. Orange $=$ surface current, green $=$ intermediate current, blue $=$ deep-ocean current. Yellow circles $=$ Expedition 369 sites.

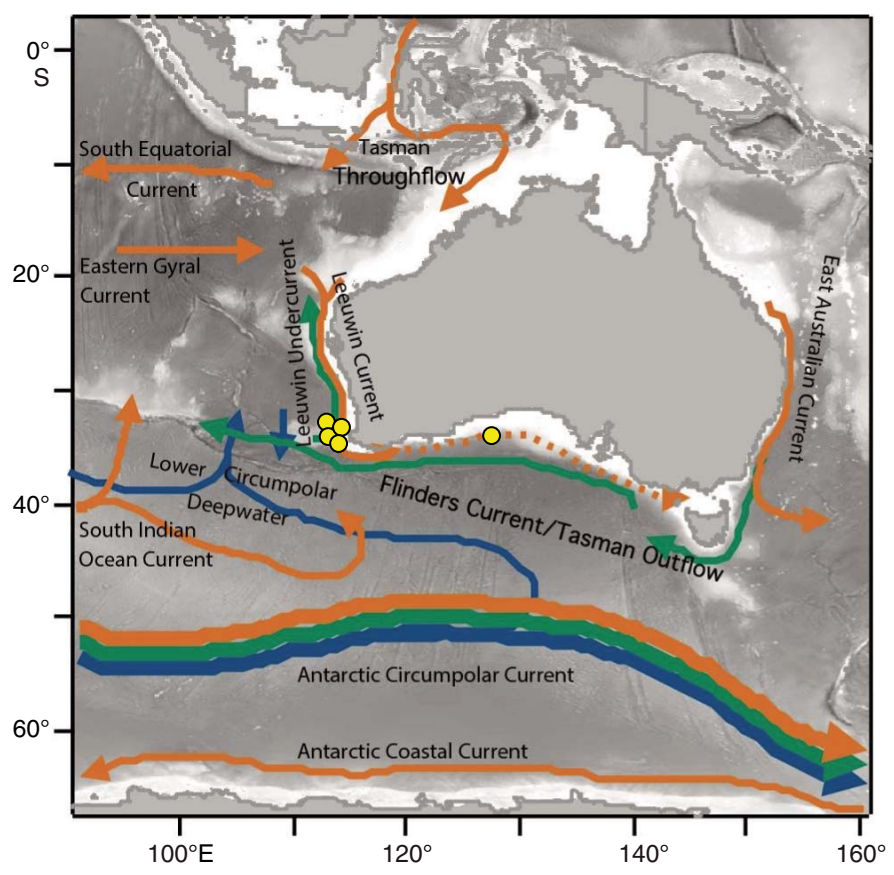

southern Australia would have been influenced more by subpolar (rather than the modern subtropical) gyres as a consequence of the closed or restricted Tasman Gateway and more southerly position of Australia (e.g., Huber et al., 2004). During the Early Eocene Climatic Optimum, however, temperatures in the southwest Pacific Ocean near Australia seem to have been warmer than climate models predicted (Hollis et al., 2012). Cooling of the Antarctic margin relative to the Australian margin near Tasmania occurred early in the opening of the Tasman Gateway, which is dated at 49$50 \mathrm{Ma}$ (Bijl et al., 2013), and the identification of a separate Southern deepwater source was possible from the late middle Eocene. (Cramer et al., 2009; Borrelli et al., 2014). However, plate tectonic reconstructions (Müller et al., 2000) indicate that separation of Australia and Antarctica near Tasmania occurred at $43 \mathrm{Ma}$, later than the oceanographic changes. Recovering material spanning this time interval, therefore, provides an important opportunity to reconcile these tectonic and paleoceanographic interpretations.

The restricted surface flow through the Indonesian Gateway is essential to the surface heat flux in the Pacific and Indian Oceans and has been linked to El Niño Southern Oscillation (ENSO) dynamics and the global ocean overturning circulation (Gordon, 1986; Godfrey, 1996; Lee et al., 2002). The gradual restriction of the Indonesian Gateway from deep-water throughflow in the late Oligocene to early Miocene to variable shallow flow in the Pliocene to Pleistocene is thought to have strongly affected surface heat distribution, with potential links to the late Neogene cooling and Northern Hemisphere glaciation (Cane and Molnar, 2001; Kuhnt et al., 2004; Karas et al., 2009).

\section{Objectives}

1. Investigate the timing and causes for the rise and collapse of the Cretaceous hot greenhouse and how this climate shift affected the climate-ocean system and oceanic biota.

Compilations of deep-sea benthic foraminiferal and bulk carbonate $\delta^{18} \mathrm{O}$ data reveal that the world ocean experienced long-term warming from the late Aptian through middle Cenomanian; maintained extremely warm temperatures from the late Cenomanian through Santonian, with peak warmth $\left(>20^{\circ} \mathrm{C}\right.$ at midbathyal depths) during the Turonian; and gradually returned to cooler values $\left(\sim 6^{\circ}-\right.$ $8^{\circ} \mathrm{C}$ at midbathyal depths) during the Maastrichtian (Huber et al., 1995, 2002, 2011; Clarke and Jenkyns, 1999; Friedrich et al., 2012; O'Brien et al., 2017). Recent benthic and planktonic $\delta^{18} \mathrm{O}$ values obtained from the Turonian at Site 258 support extreme high-latitude Turonian warmth (Huber et al., 2018). Still, these $\delta^{18} \mathrm{O}$ values are problematically low and seem to defy straightforward explanations (Bice et al., 2003). Compared with existing stable isotope data ( $\mathrm{Hu}-$ ber et al., 1995, 2002), the new analyses showed large changes at times of known climatic shifts.

Although the Cretaceous has long been characterized as too warm to sustain continental ice sheets (e.g., Barron, 1983; Frakes et al., 1992; Huber et al., 2002; Hay, 2008), coincidences between sea level variations (deduced from sequence stratigraphy) and $\delta^{18} \mathrm{O}$ records have been proposed by some authors as evidence for the occasional existence of polar ice (e.g., Barrera et al., 1997; Miller et al., 1999, 2005; Stoll and Schrag, 2000; Gale et al., 2002; Bornemann et al., 2008) and winter sea ice (Bowman et al., 2012). The "greenhouse glaciers" hypothesis has been countered by evidence for diagenetic influence on bulk carbonate oxygen isotope records and stable tropical planktonic and benthic foraminiferal $\delta^{18} \mathrm{O}$ data across several of the proposed cooling intervals (Huber et al., 2002; Moriya et al., 2007; Ando et al., 2009; MacLeod et al., 2013), Furthermore, TEX values from DSDP Site 511 suggest sea-surface temperatures of $25^{\circ}-30^{\circ} \mathrm{C}$ during the Hauterivian to Aptian interval (Jenkyns et al., 2012; O’Brien et al., 2017).

High-resolution isotopic studies of samples from Expedition 369 sites should advance our understanding and improve geographic documentation of major global climatic warming and cooling transitions during the Cretaceous. Recovery of more complete sections will lead to biostratigraphic refinements and improved regional to global correlations.

\section{Determine the relative roles of productivity, ocean temperature, and ocean circulation at high southern latitudes during Creta- ceous oceanic anoxic events (OAEs).}

OAEs are defined as short-lived ( $<1 \mathrm{My}$ ) episodes of enhanced deposition of organic carbon in a wide range of marine environments (Schlanger and Jenkyns, 1976) and are associated with prominent carbon isotope excursions in marine and terrestrial sequences (Jenkyns, 1980, 2010; Arthur et al., 1988; Gröcke et al., 1999; Jahren et al., 2001; Ando et al., 2002; Jarvis et al., 2006). Triggering of OAEs has been attributed to a rapid influx of volcanogenic and/or methanogenic $\mathrm{CO}_{2}$ sources leading to abrupt temperature rise and an accelerated hydrological cycle, increased continental weathering 
and nutrient discharge to oceans and lakes, intensified upwelling, and increased organic productivity. Globally expressed Cretaceous OAEs occurred during the early Aptian (OAE 1a; 120 Ma) and at the Cenomanian/Turonian (C/T) boundary (OAE 2; 94 Ma), and regionally recognized events occurred during the early Albian (OAE 1b; 111 Ma) and late Albian (OAE 1d; 100 Ma).

Cretaceous OAEs are best known from the Atlantic/Tethyan basins and surrounding continents, and records from the Indian Ocean are limited. The presence of black shales with as much as $6.9 \%$ total organic carbon (TOC) in the GAB (Totterdell et al., 2008), $11 \%$ at Site U1513, and as much as $14 \%$ at Site U1516 suggest water may even have been euxinic in the region during deposition of OAE 2. OAE deposits should have been present at Kerguelen (Ocean Drilling Program [ODP] Site 1138) and Exmouth Plateaus and adjacent basinal areas (primarily ODP Site 763), but drilling strategies and poor recovery resulted in all of the cores missing the OAE record.

Recovery of a continuous record of the C/T boundary OAE 2 was anticipated at GAB Site U1512, western Mentelle Basin Site U1513, and northern Mentelle Basin Site U1514. Actual recovery at Expedition 369 sites was different (see Principal results) but included apparently excellent records of OAE 2 . At all sites, the anticipated OAE 2 interval is at a shallow burial depth ( 260-460 meters below seafloor) where sediments are thermally immature and preservation of biogenic material is good to excellent. Future studies will compare the Expedition 369 sites and other high-latitude OAE 2 sites to establish (1) whether significant changes in ocean circulation were coincident with OAE 2 (e.g., MacLeod et al., 2008; Martin et al., 2012), (2) over what depth ranges these changes, if any, occurred (Zheng et al., 2013), and (3) whether OAE 2 in the high-latitude Southern Hemisphere was coincident with major changes in sea-surface temperatures (Jarvis et al., 2006). We are particularly interested in establishing whether the $\mathrm{C} / \mathrm{T}$ succession contained evidence for the "Plenus cold event," an important cooling $\left(\sim 4^{\circ}\right.$ to $>5^{\circ} \mathrm{C}$ ) event within OAE 2 known from the Northern Hemisphere. This event is associated with changes in surface water circulation (e.g., Zheng et al., 2013) and reoxygenation of bottom water, but it remains unclear whether the Plenus cold event was a global or regional phenomenon. Data from the high southern latitudes are currently lacking (Jenkyns et al., 2012) and would address this critical gap in our model for OAE 2.

\section{Identify the main source regions for deep-water and intermediate water masses in the southeast Indian Ocean and how these changed during the Gondwana breakup.}

Over the past few years, study of Cretaceous intermediate and deep-water circulation patterns has been galvanized by an increase in published neodymium $(\mathrm{Nd})$ isotopic data (e.g., Jiménez Berrocoso et al., 2010; Robinson et al., 2010; MacLeod et al., 2011; Martin et al., 2012; Murphy and Thomas, 2012; Jung et al., 2013; Moiroud et al., 2013; Voigt et al., 2013; Zheng et al., 2013). Nd isotopic values (expressed as $\varepsilon \mathrm{Nd}$ ) have emerged as a promising proxy for reconstructing past circulation and are applicable across a wide range of water depths, including abyssal samples deposited below the carbonate compensation depth.

Typically measured on either phosphatic fossils (fish teeth, bones, and scales) or oxides leached from bulk samples, $\varepsilon \mathrm{Nd}$ values record a depositional to early diagenetic bottom water signature generally resistant to later diagenetic overprinting (Martin and Scher, 2004). The bottom water signature, in turn, reflects the $\varepsilon \mathrm{Nd}$ value of the source region of that water mass because $\mathrm{Nd}$ enters the ocean largely as riverine or eolian input, has a residence time shorter than the mixing time of the oceans, and has semiconsolidated behavior. Because $\varepsilon \mathrm{Nd}$ values in likely source regions vary by $10-15$ units compared to an analytical precision of $\sim 0.3$ units, stratigraphic trends in $\varepsilon N d$ can be used to infer changes in circulation and mixing patterns through time. However, $\varepsilon \mathrm{Nd}$ values of samples are also influenced by local and global volcanic inputs, and the bottom water $\varepsilon \mathrm{Nd}$ signature of a water mass can be modified during circulation by a high particle flux or boundary exchange, especially near detrital sources.

Cretaceous $\varepsilon \mathrm{Nd}$ data have been used to test, refine, and revise earlier circulation hypotheses that were based largely on carbon and oxygen isotopes. $\mathrm{Nd}$ isotopic data have also documented correlation between $\varepsilon \mathrm{Nd}$ shifts and both long-term climate trends and shorter bioevents (e.g., OAE 2) and demonstrated a degree of complexity within and among sites not predicted by early studies. The latter is particularly true for the Southern Ocean, where circulation changes, water column stratification changes, volcanic inputs, and establishment of a widespread source of Southern Component Water have all been invoked to explain observed patterns (e.g., Robinson and Vance, 2012; Murphy and Thomas, 2012; Jung et al., 2013; Voigt et al., 2013). Nd studies of samples from sites representing a range of depths within the Mentelle Basin/Naturaliste Plateau, when combined with parallel paleotemperature estimates from $\delta^{18} \mathrm{O}$ and $\mathrm{TEX}_{86}$ and documentation of calcareous microfossil assemblages, should help reduce uncertainty in interpretation of previous studies.

\section{Characterize how oceanographic conditions changed at the Men- telle Basin during the Cenozoic opening of the Tasman Gateway and restriction of the Indonesian Gateway.}

The Mentelle Basin sites are well positioned to monitor paleoceanographic variations in the Leeuwin Current/Undercurrent system. The surface Leeuwin Current is unique in that it flows poleward along the eastern boundary of the Indian Ocean (Figure F3). The current is caused by the north-south gradient between cooler waters to the south and warm surface waters along the northwestern Australian coast. These warmer waters are derived from the Indonesian Throughflow (ITF), which overrides the prevailing wind stress and results in the poleward flow (Pattiaratchi, 2006; Godfrey, 1996; Domingues et al., 2007; Waite et al., 2007). The strength of the Leeuwin Current varies seasonally with ITF strength and interannually with ENSO dynamics, strengthening in winter and under La Niña conditions. The intermediate Leeuwin Undercurrent is derived from an eddy system associated with the Flinders Current near the Naturaliste Plateau (Middleton and Cirano, 2002; Waite et al., 2007; Meuleners et al., 2007; Divakaran and Brassington, 2011). The Flinders Current and Leeuwin Undercurrent are conduits of the Tasman leakage, a pathway for return flow to the North Atlantic Ocean of deepwater upwelled in the Pacific and a component of the Southern Hemisphere supergyre that links the subtropical gyres of the Atlantic, Pacific, and Indian Oceans (Speich et al., 2002, 2007; Ridgway and Dunn, 2007; van Sebille et al., 2012). The Tasman leakage allows interconnection of Antarctic Intermediate Water (AAIW) in the Pacific, Atlantic, and Indian Oceans, and the Flinders Current-Leeuwin Undercurrent system seems to play a role in the conversion of Subantarctic Mode Water to AAIW (Ridgway and Dunn, 2007). Deepwater in the Mentelle Basin is derived from Antarctic Bottom Water (AABW) and lower Circumpolar Deep Water that enter the Perth Basin between the Mentelle Basin and Broken Ridge, with substantial upwelling of AABW in the 
southern portion of the Perth Basin (Sloyan, 2006; McCartney and Donohue, 2007).

Coring in the Mentelle Basin complements previous drilling around Australia, especially off Western Australia (DSDP Leg 27, ODP Legs 122 and 123, and IODP Expedition 356) and southern Australia and Tasmania (ODP Legs 182 and 189). Coring recovered Paleocene to Eocene and upper Miocene to recent sequences at deep-water and intermediate-water locations. Recovered material from this expedition will contribute to investigations of (1) the early Paleogene greenhouse climate at a high-latitude $\left(\sim 60^{\circ} \mathrm{S}\right)$ site, (2) oceanographic changes in the early stages of the opening of the Tasman Gateway, and (3) oceanographic changes during the late stages of restriction of the Indonesian Gateway.

\section{Resolve questions about the volcanic and sedimentary origins of the basin and provide stratigraphic control on the age and nature of the prebreakup succession.}

The interlinked aspects of the geology and evolution of the Naturaliste Plateau and Mentelle Basin suggest that recovering the volcanic rocks at the Valanginian/late Hauterivian unconformity will further our understanding of this region. Drilling the unconformity provides information on

- The timing and position of the breakup (both on the western and southern margin, using paleomagnetic studies and ${ }^{40} \mathrm{Ar} /{ }^{39} \mathrm{Ar}$ dating of lavas);

- The nature of the various phases of volcanism (core description, petrophysics, and geochemical and isotopic study);

- Geographic and environmental reconstructions; and

- The depositional history of the basin.

The principal cause of high-amplitude discontinuous reflectors overlying the interpreted Valanginian breakup unconformity corresponds to extrusive volcanics that flowed into the Mentelle Basin at the time of the breakup with Greater India. Drilling into the Valanginian volcanics and pre-Valanginian sediments (Sites U1513 and U1515) provides stratigraphic control on the age and nature of the prebreakup succession and early rifting in the Mentelle Basin. Dating and analysis of the postbreakup sediments will provide needed information about the development of the Mentelle Basin and particularly the influence of the later rifting with Antarctica. The results from this expedition will address a number of key tectonics questions for the region.

\section{Principal results}

\section{Site U1512}

\section{Site background and objectives}

The objective for coring Site U1512 (Table T1) was to obtain a continuous Upper Cretaceous record of marine black shales in the GAB across OAE 2, which straddles the C/T boundary. Our plan was to compare the Site U1512 sediment record with coeval Expedition 369 sequences cored in the Mentelle Basin to characterize the geochemical and biological responses to extreme global carbon cycle perturbations in different paleoceanographic settings at high southern latitudes. Site U1512 lies in the GAB in 3000 m of water on the continental slope. During the Cretaceous, the GAB was situated in the central to eastern end of a partial seaway (the AAG), with the Mentelle Basin and Naturaliste Plateau in the open ocean at the western gateway that connected the AAG with the southern Indian Ocean. Although the OAE 2 target was not reached because it is significantly deeper than anticipated, studies of the recovered se- quence of early Turonian to late Santonian marine claystone will provide new insight into the evolution of Late Cretaceous climate and oceanography in the region of the AAG.

\section{Lithostratigraphy}

The sedimentary sequence in Hole U1512A is divided into two main lithostratigraphic units (Figure F4). Unit I is a $10.06 \mathrm{~m}$ thick Pleistocene sequence of pinkish to white calcareous ooze with sponge spicules. The unit extends from the beginning of the hole to $10.06 \mathrm{~m}$ core depth below seafloor, Method A (CSF-A) (Sections 369-U1512A-1R-1 through 2R-1; 0-10.2 m CSF-A). The unit consists of medium and thick beds that are massive and lack physical and biological sedimentary structures. In this unit, biogenic grains are the major constituent, and they comprise dominant calcareous nannofossils, abundant foraminifers, and common sponge spicules. Unit II is a $690.32 \mathrm{~m}$ thick sequence of silty clay that gradationally transitions into silty claystone (Sections $2 \mathrm{R}-1$ through $73 \mathrm{R}-\mathrm{CC}$ at the bottom of the hole; 10.2-701.4 m CSF-A). This unit is black to dark gray mottled silty claystone composed of quartz, clay minerals, pyrite, siderite, and dolomite with varying degrees of bioturbation. Micropaleontological analysis indicates a Late Cretaceous (Santonian to Turonian) age for this unit. Unit II is further divided into Subunits IIa (silty clay) and IIb (silty claystone) based on the degree of sediment lithification. Subunit IIa is $75.10 \mathrm{~m}$ thick and composed of very dark greenish gray to black unlithified silty clay. It is characterized by the presence of pyrite, both as nodules and in a disseminated form within the silty clay. Zeolite, foraminifers, calcareous nannofossils, and sponge spicules are present in trace amounts throughout the subunit. Inoceramid bivalve fragments and alteration halos occur frequently throughout the subunit. Subunit IIb is $615.22 \mathrm{~m}$ thick and composed of lithified black silty claystone. Included in this subunit are 23 thin to medium beds of glauconitic and sideritic sandstone that are no thicker than $32 \mathrm{~cm}$ and are mostly massive with normal grading. Bioclast traces present in this subunit include foraminifers, calcareous nannofossils, radiolarians, sponge spicules, and organic matter.

\section{Biostratigraphy and micropaleontology}

Samples from all Hole U1512A core catchers were analyzed for calcareous nannofossils, planktonic foraminifers, and benthic foraminifers. In addition, calcareous nannofossil assemblages were evaluated from split core sections. Observations of other distinctive and potentially age or environmentally diagnostic microfossil groups, such as organic-walled dinoflagellate cysts (dinocysts), radiolarians, fish debris, and inoceramid prisms, were also made in all core catcher samples. Calcareous nannofossil datums form the chronologic framework for Hole U1512A because they are most consistently present. In contrast, planktonic foraminifers are rare. Similarly, rare dinocyst taxa from Cores 369-U1512A-47R through 70R ( 440-672 m CSF-A) and radiolarians from Cores 5R through 35R ( 38-333 m CSF-A) provide valuable additional age confirmation of Upper Cretaceous sediments.

Stratigraphic positions of calcareous nannofossil biozones and age assignments for Site U1512 are presented in Figure F4. The calcareous plankton indicate Pliocene to Pleistocene-age sediments from 0 to $11.63 \mathrm{~m}$ CSF-A, but no ages were assigned to samples from this level to $42.40 \mathrm{~m}$ CSF-A because either no microfossils were found or studied samples include mixed Cretaceous and Neogene ages. Calcareous nannofossils occur throughout most of the underlying Santonian to Albian sequence, although they are mostly rare with generally moderate to poor preservation. Cretaceous 
Table T1. Expedition 369 hole summary. DSF = drilling depth below seafloor. APC = advanced piston corer, HLAPC = half-length APC, XCB = extended core barrel, $\mathrm{RCB}=$ rotary core barrel. Download table in CSV format.

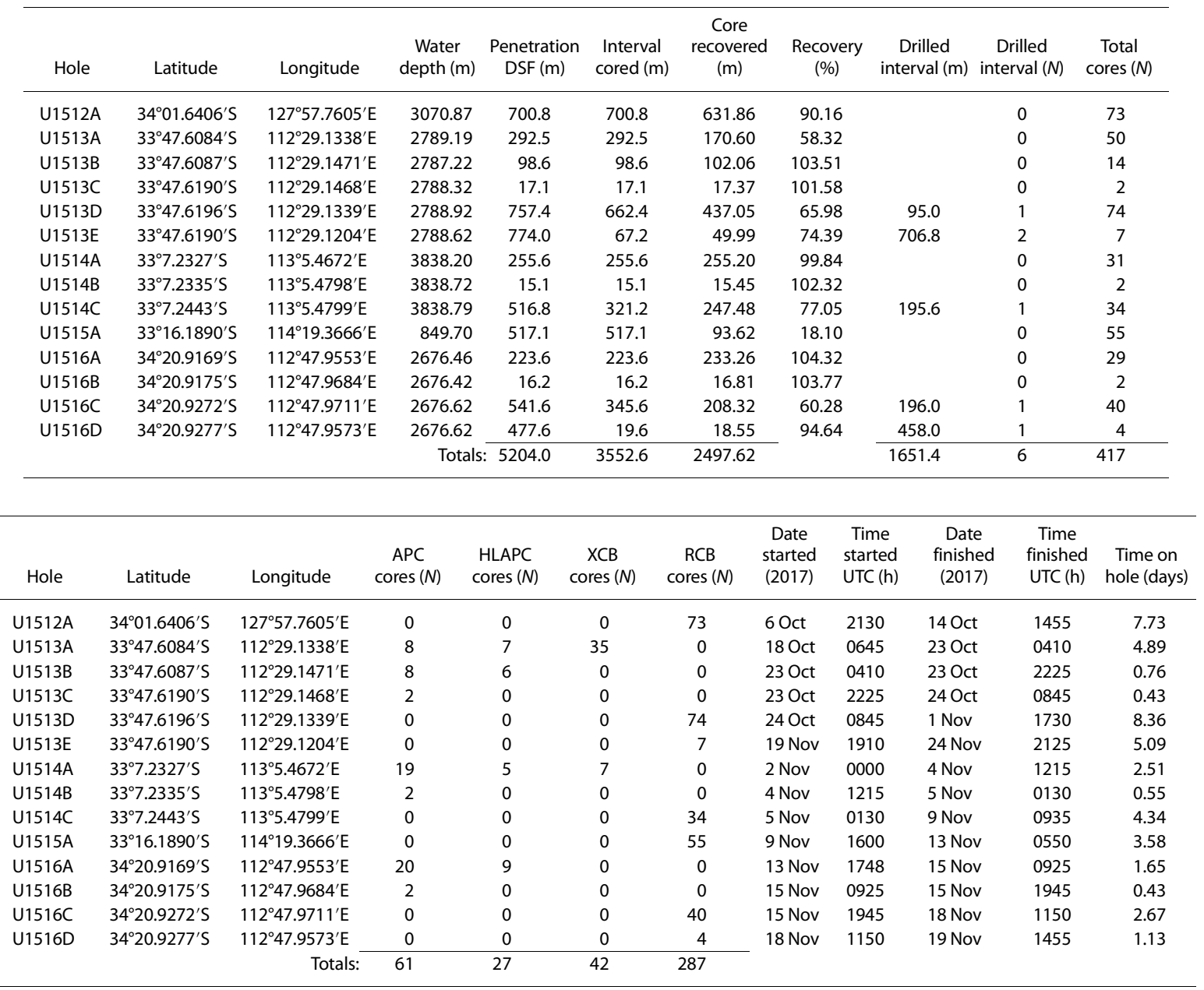

planktonic foraminifers are rare and poorly preserved. However, where present, the ages of these foraminifers are consistent with those of calcareous nannofossils. No calcareous microfossils were found in an upper Turonian to Coniacian interval from 211 to 296 m CSF-A.

Tubular agglutinated forms dominate benthic foraminiferal assemblages at Site U1512 and indicate either a lower to midbathyal environment or a marginal/restricted environment throughout the Late Cretaceous.

\section{Paleomagnetism}

The natural remanent magnetizations (NRMs) of all archivehalf core sections and 21 discrete samples collected from the working halves of Hole U1512A were measured. The archive halves were stepwise treated with an up to $30 \mathrm{mT}$ alternating field (AF) demagnetization field and measured with the pass-through superconducting rock magnetometer (SRM) at $5 \mathrm{~cm}$ intervals. The NRM intensity of the section is relatively weak and varies from $1.5 \times 10^{-5}$ to $7.8 \times 10^{-2} \mathrm{~A} / \mathrm{m}$ with a mean of $5.5 \times 10^{-4} \mathrm{~A} / \mathrm{m}$. The drilling-induced magnetic overprints can generally be removed by AF demagnetization at $10-20 \mathrm{mT}$. Inclinations of the characteristic remanent magnetizations (ChRMs) are predominantly negative, ranging from around $-70^{\circ}$ to $-20^{\circ}$ and indicating predominantly normal polarity. The uppermost $\sim 80 \mathrm{~m}$ display a very noisy signal because of the significant coring disturbance (biscuiting) introduced by the rotary coring process. Positive inclination values occur between 0 and 75 , 175 and 190, and 256 and 259 m CSF-A. The intervals from $\sim 0$ to 75 and 175 to $100 \mathrm{~m}$ CSF-A also exhibit sporadic or consecutive negative ChRM inclinations mixed with dominantly positive inclinations, making it impossible to assign magnetic polarity. The interval between 256 and 259 m CSF-A exhibits consistent downwardpointing paleomagnetic inclinations, defining a zone of reversed polarity probably associated with a short geomagnetic excursion.

Shipboard micropaleontological studies suggest that Core 369U1512A-5R (38.4-47.4 m CSF-A) is Santonian and the base of Core $73 \mathrm{R}$ is early Turonian. Therefore, the majority of the sedimentary cores from 38.4 to $700 \mathrm{~m}$ CSF-A document the uppermost segment of the 41.5 My Cretaceous Normal Superchron (CNS) C34n.

\section{Petrophysics}

Physical property data were obtained with the Whole-Round Multisensor Logger (WRMSL), Natural Gamma Radiation Logger (NGRL), P-wave velocity caliper (PWC), Section Half Multisensor Logger (SHMSL), and discrete samples. WRMSL $P$-wave measurements were discontinued deeper than Core 369-U1512A-11R because of poor contact between the core sections, their liners, and the caliper. Natural gamma radiation (NGR) values (Figure F4) average 32.8 counts/s, and bulk density estimates from gamma ray attenuation (GRA) average $1.7 \mathrm{~g} / \mathrm{cm}^{3}$. GRA bulk density values in siltstone/claystone do not exceed $2.2 \mathrm{~g} / \mathrm{cm}^{3}$, whereas in siderite 
Figure F4. Site U1512 summary. See Table T5 in the Site U1512 chapter (Huber et al., 2019a) for calcareous nannofossil event definitions.

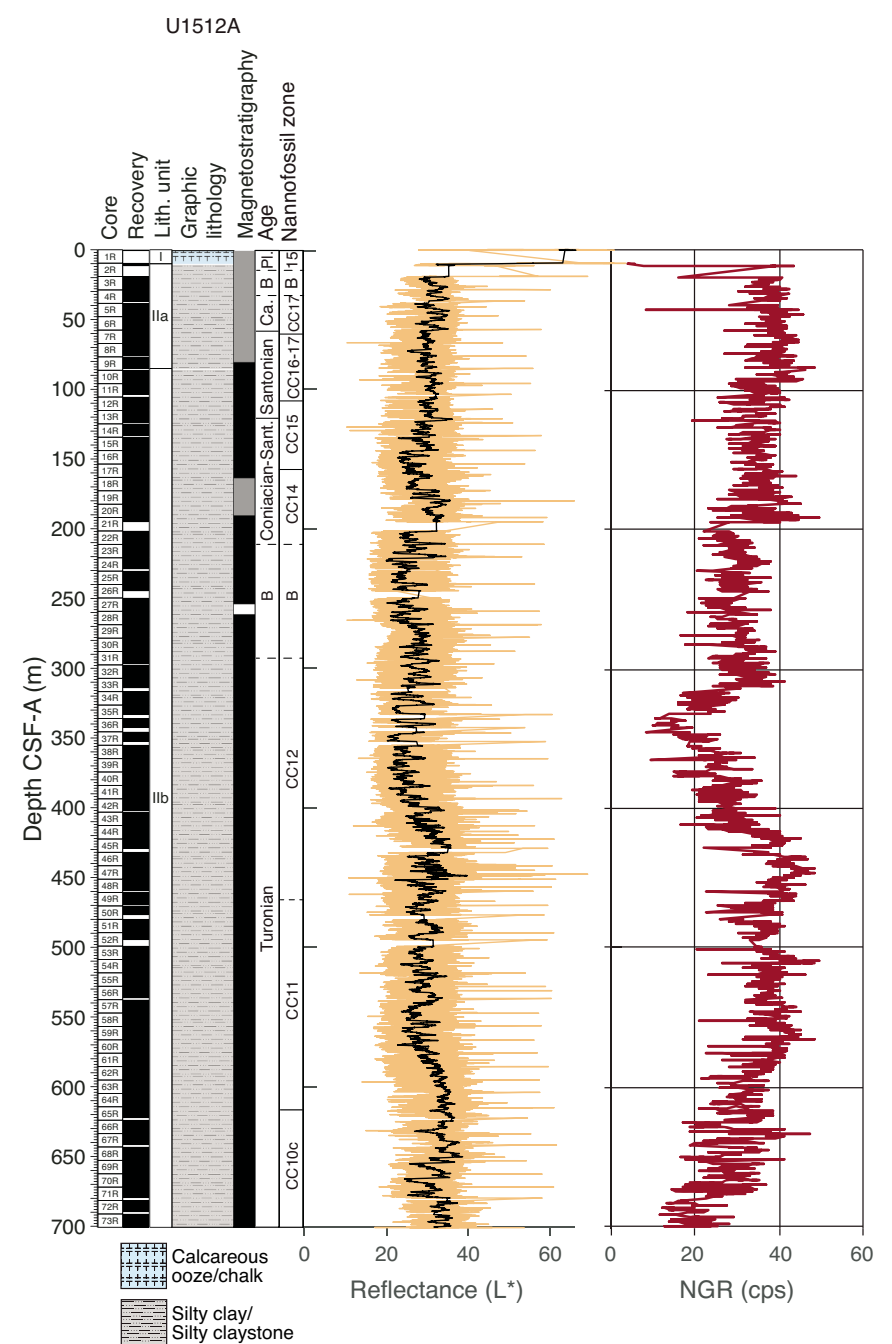

nodules and glauconitic sandstones, they increase to $3.28 \mathrm{~g} / \mathrm{cm}^{3}$. WRMSL magnetic susceptibility values average 9.35 instrument units (IU) and do not exceed 16 IU in claystone and siltstone, but magnetic susceptibility increases to 253.58 IU in glauconitic sandstone and siderite; point measurements from the SHMSL agree with these trends. At scales longer than $10 \mathrm{~m}$, the NGR and magnetic susceptibility records do not correlate over silty/clayey intervals from Cores $3 \mathrm{R}$ through $15 \mathrm{R}$, possibly because of the high abundance of pyrite differentially influencing the magnetic susceptibility values. The NGR and GRA bulk density records display parallel trends in this interval. From Core 16R to Core 62R, pyrite abundance markedly decreases, and all three data types (magnetic susceptibility, NGR, and GRA bulk density) display similar trends. From Core 63R to Core 73R, both NGR and magnetic susceptibility decrease, but GRA bulk density remains stable. At shorter scales $(<10 \mathrm{~m})$, magnetic susceptibility, GRA bulk density, and NGR show high-amplitude, 3-5 m thick cycles in Cores 10R through 19R, 34R through $43 R$, and $62 \mathrm{R}$ through $73 \mathrm{R}$. $P$-wave velocity in the silty claystone ranges from 1670 to $2346 \mathrm{~m} / \mathrm{s}$, although faster velocities $(3397-5774 \mathrm{~m} / \mathrm{s})$ were obtained for the discrete layers of sideritic sandstone. High-resolution $(2 \mathrm{~cm})$ reflectance spectroscopy and colorimetry data from archive-half core sections display high-amplitude variability.

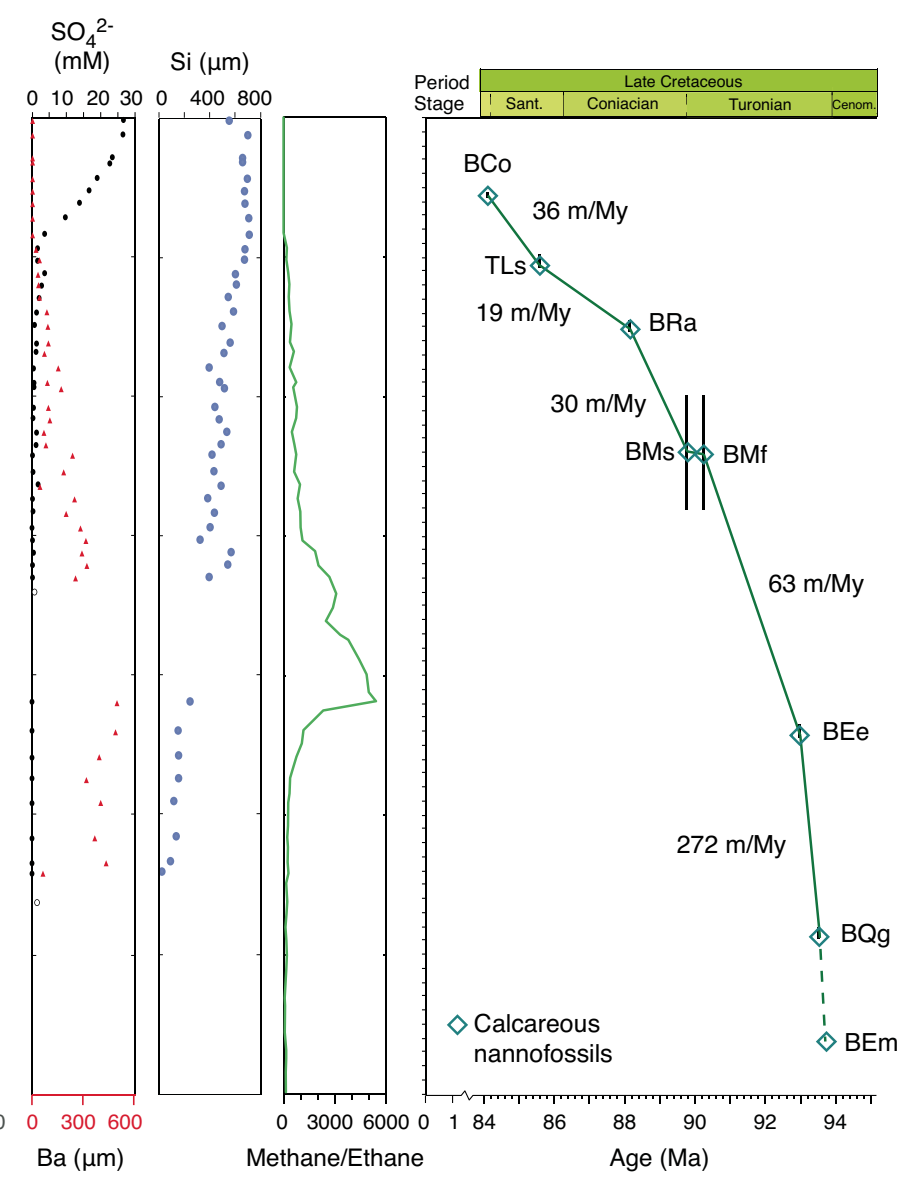

On average, three discrete moisture and density (MAD) samples were taken from each core. Overall, the MAD results show that bulk density increases and grain density and porosity decrease. The bulk density of the dark silty claystone is $1.54-2.37 \mathrm{~g} / \mathrm{cm}^{3}$, and the density of the sideritic sandstone intervals ranges from 3.21 to 3.49 $\mathrm{g} / \mathrm{cm}^{3}$. The porosity of the silty claystone is $28 \%-65 \%$ with most measurements between $40 \%$ and $48 \%$. The porosity of the sideritic sandstone ranges from $5 \%$ to $13 \%$.

Potassium (K), uranium (U), and thorium (Th) content were deconvolved from the NGR data. U/Th ratios are $<0.2$ throughout the entire hole, indicating oxic conditions during deposition. K/Th ratios sharply decrease in the uppermost $100 \mathrm{~m}$, possibly because of the presence of salt in this interval, which may increase the $\mathrm{K}$ content.

One downhole logging run measured NGR, density, sonic velocity, and resistivity values of the borehole wall using a modified triple combination (triple combo) tool string with an added Dipole Shear Sonic Imager (Quambo). Excellent borehole stability and favorable low-heave weather conditions permitted logging of the entire open borehole. Inclinometer readings progressively increase from roughly $0^{\circ}$ shallower than $210 \mathrm{~m}$ wireline log matched depth below seafloor (WMSF) to $27^{\circ}$ near the base of the hole, indicating that borehole orientation deviated from vertical during coring. 
Background trends in the density, NGR, and resistivity logs are relatively stable in the upper $300 \mathrm{~m}$ of the borehole. Below that interval, each of these three logs records minimum values near $325 \mathrm{~m}$ WMSF, which increase downhole to plateaus approaching maxima for the hole. Additionally, the density and resistivity logs preserve thin spikes in values that likely correspond to the thin sideritic and glauconitic sandstone beds commonly observed (see Lithostratigraphy). In general, downhole measurements record trends similar to those observed in the physical properties measured from the cores, such as meter-scale cyclicity in NGR, and provide a continuous petrophysical stratigraphy that spans occasional gaps in core recovery.

\section{Geochemistry}

The geochemistry program was designed to characterize the composition of interstitial water and bulk sediments and to assess the potential presence of volatile hydrocarbons for routine safety monitoring. A total of 73 headspace gas samples were taken; hydrocarbons were detected in 68 samples. In Cores 369-U15812A-1R through 9R, headspace samples were free of gas or had very low concentrations. Below this, methane was the dominant gas detected (as high as 104,000 ppmv), with very minor ethane and occasional propane (as high as 653 and 148 ppmv, respectively). Methane/ethane ratios (Figure F4) suggest a transition from biogenic production shallower than $\sim 473 \mathrm{~m}$ CSF-A to possible thermogenic sources below that depth.

For interstitial water analyses, 46 samples were recovered from whole-round squeezing of sediment intervals. As a result of sediment lithology, interstitial water yield was low for the majority of the cores recovered deeper than Core 369-U1512A-12R ( 115 m CSF-A). The final interstitial water sample was taken from Core 59R ( $\sim 560 \mathrm{~m}$ CSF-A). Interstitial water salinity generally decreases with depth because of decreases in sulfate $\left(\mathrm{SO}_{4}{ }^{2-}\right)$, magnesium $(\mathrm{Mg})$, and $\mathrm{K}$ concentrations and general decreases in sodium $(\mathrm{Na})$, bromide $\left(\mathrm{Br}^{-}\right)$, and chloride $\left(\mathrm{Cl}^{-}\right)$possibly caused by low-salinity water present at greater depths. The dissolved $\mathrm{Mg}, \mathrm{K}$, and boron (B) concentration profiles reflect alteration of volcanic material and clay mineral formation. Sulfate is readily depleted in the upper $\sim 93 \mathrm{~m}$ (Core 10R) of the sedimentary column (Figure F4) because of intense bacterial $\mathrm{SO}_{4}{ }^{2-}$ reduction and is accompanied by synchronous increases in ammonium $\left(\mathrm{NH}_{4}^{+}\right)$, alkalinity, and lithium (Li), along with high barium $(\mathrm{Ba})$ values in samples below the depth where $\mathrm{SO}_{4}{ }^{2-}$ is exhausted. Alkalinity ranges from 4.4 to $16.52 \mathrm{mM}$ with a maximum at $93.55 \mathrm{~m}$ CSF-A, and $\mathrm{pH}$ ranges from 7.76 to 7.97 with a slight decrease downhole; both measurements were limited to the uppermost $\sim 130 \mathrm{~m}$ because of the small interstitial water volumes obtained from deeper samples. Dissolved calcium (Ca) and to a lesser degree strontium ( $\mathrm{Sr}$ ) increase toward $300 \mathrm{~m} \mathrm{CSF-A,} \mathrm{more}$ than likely due to carbonate diagenesis. Decreasing $\mathrm{Ca}$ and $\mathrm{Sr}$ concentrations deeper than $300 \mathrm{~m}$ CSF-A indicate that carbonate dissolution/recrystallization may prevail at depth. Dissolved silicon $(\mathrm{Si})$ shows a short positive excursion between 310.68 and $329.27 \mathrm{~m}$ CSFA (Figure F4), reflecting the presence of biogenic opal-A in the sediment; lower values from deeper than Core 35R may be due to opal$\mathrm{A} /$ cristobalite and tridymite $(\mathrm{CT})$ transformation. The elevated manganese $(\mathrm{Mn})$ concentration demonstrates the reducing character of the entire sedimentary sequence.

$\mathrm{CaCO}_{3}$ content from Cores 369-U1512A-1R through 73R varies from 0.06 to $6.66 \mathrm{wt} \%$, except for Core $1 \mathrm{R}$, which is composed of calcareous ooze with $90.97 \% \mathrm{CaCO}_{3}$. The low carbonate percentages in Cores $2 \mathrm{R}$ through $73 \mathrm{R}$ reflect the very low contribution of calcareous nannofossil and foraminiferal components to the sedi- ment. TOC, which is predominantly terrestrially derived, ranges from 0.20 to $1.31 \mathrm{wt} \%$, and total nitrogen $(\mathrm{TN})$ ranges from $<0.01$ to $0.10 \mathrm{wt} \%$. TOC/TN ratios generally decrease with depth, ranging from 6.30 to 31.19 . This trend is likely caused by decomposition of $\mathrm{N}$-containing terrestrial organic matter that released carbon as methane but retained the produced $\mathrm{NH}_{4}{ }^{+}$in clays. Eight freezedried bulk sediment samples with TOC $>1 \mathrm{wt} \%$ were analyzed on the source rock analyzer. The results show very low hydrogen index values, and the kerogen in the samples was classified as Type III, suggesting a predominantly terrestrial origin for the organic carbon.

\section{Stratigraphic correlation}

Only one hole was cored at Site U1512 with the rotary core barrel (RCB) system. Recovery was excellent, exceeding $100 \%$ in 24 of the 73 cores recovered, and total recovery was $90 \%$. Distinctive features for correlation included large-scale $(>10 \mathrm{~m})$ trends and changes of variable amplitude on shorter scales (1-5 m) in NGR and magnetic susceptibility data, as well as distinct peaks in these measurements corresponding to sandstone layers. Despite being unable to correlate cored intervals, recognition of matching features in NGR records from the Hole U1512A cores and wireline logs permitted correlation from the CSF-A scale to the WMSF scale.

\section{Age-depth model and sedimentation rates}

Sedimentation rates are $36 \mathrm{~m} / \mathrm{My}$ for Santonian Zones CC17 and CC16 and $19 \mathrm{~m} / \mathrm{My}$ for Zone CC15 (Figure F4). The interval from the uppermost Coniacian to middle Turonian, which encompasses Zones CC14 and CC13, has an average sedimentation rate of $63 \mathrm{~m} / \mathrm{My}$. Sedimentation rates accelerate markedly in the lower to middle Turonian Zone CC12 to $272 \mathrm{~m} / \mathrm{My}$. This estimate does not correct for the hole deviation from vertical (see Petrophysics).

\section{Site U1513}

\section{Background and objectives}

The objectives for coring Site U1513 (Table T1) on the western margin of the Mentelle Basin were to (1) obtain a continuous Late Cretaceous sediment record to better document the rise and fall of the Cretaceous hot greenhouse climate at southern high latitudes ( $\sim 60^{\circ} \mathrm{S}$ paleolatitude), (2) characterize how oceanographic conditions changed during the Cenozoic opening of the Tasman Gateway and the restriction of the Indonesian Gateway, and (3) obtain basalt from the base of the sedimentary sequence to provide stratigraphic control on the age and nature of the pre-Gondwana breakup succession. A particularly important goal was to obtain a complete OAE 2 sequence across the $\mathrm{C} / \mathrm{T}$ boundary to characterize associated biotic, oceanographic, and climatic changes. The Site U1513 sequence will be compared with coeval Expedition 369 sections cored elsewhere on the Mentelle Basin and with other ocean drilling (e.g., DSDP Site 258) and industry data from the Western Australia margin and in the GAB to identify any regional differences in the geochemical and biological responses to the OAEs and Cretaceous and Neogene ocean circulation history.

\section{Lithostratigraphy}

The Site U1513 cored section is divided into six lithostratigraphic units, five sedimentary and one igneous, based on a combination of data from Holes U1513A, U1513B, U1513D, and U1513E. Lithostratigraphic units and boundaries are defined by changes in lithology identified by macroscopic core description, microscopic examination of smear slides and thin sections, and X-ray diffraction (XRD) and X-ray fluorescence (XRF) analyses. Lithostratigraphic Unit I is a $64.93 \mathrm{~m}$ thick Pleistocene to late Miocene sequence of 
light gray to pale yellow calcareous ooze and nannofossil ooze with sponge spicules. Unit II is a 182.93 m thick Campanian to Cenomanian sequence of white to greenish gray calcareous and nannofossil ooze/chalk and clayey nannofossil chalk with intervals of silicified limestone. Unit III is a $21.87 \mathrm{~m}$ thick Cenomanian sequence of alternating greenish gray, light gray, and black nannofossil-rich claystone. Unit IV is a $187.12 \mathrm{~m}$ thick sequence of Cenomanian to Albian black claystone and nannofossil-rich claystone. Unit V, described only in Hole U1513D, is a $234.25 \mathrm{~m}$ thick Aptian to Valanginian (tentatively determined from paleomagnetic measurements) sequence of sandstone with siltstone and silty claystone. Unit VI is an $82.2 \mathrm{~m}$ thick alternation of extrusive basalt flows and breccia intruded by a diabase dike. A sharp boundary is present between Units V and VI. The top of Unit VI is defined by flow-top breccia with an altered matrix that grades downsection into a massive plagioclase-phyric basalt flow. The unit is composed of five extrusive sequences intercalated with four volcaniclastic breccia beds that show graded structures and are defined as lithologic Units 1-7. Each extrusive sequence is generally bounded by chilled margins but also by faults or textural and color changes. Most discrete flows appear to be massive, thin sheets of olivine \pm pyroxene- or plagioclase-phyric (some megacrystic) basalt. The least-altered portions of the lowermost sequence (Unit 7) show a higher degree of vesicularity and highly angular vesicles that may indicate subaerial to very shallow eruption depths. A xenolith-bearing diabase dike intrudes the flow sequences. The contact between the xenolith-bearing diabase dike and the extrusive is defined by either faulted or chilled margins with alteration halos. These flows show a lesser degree of alteration in Hole U1513E than in Hole U1513D, and preliminary megascopic and thin section analyses reveal the original porphyritic, microcrystalline, or vesicular textures, with some of the bottom flows showing interesting crosscutting lineation features and absence of minor intrusion intervals.

\section{Biostratigraphy and micropaleontology}

Samples from all core catchers from Holes U1513A and U1513D and selected samples from Hole U1513B were analyzed for calcareous nannofossils, planktonic foraminifers, and benthic foraminifers. In addition, samples from split core sections were also evaluated for calcareous nannofossils and/or planktonic foraminiferal assemblages, as necessary. Observations of other distinctive and potentially age or environmentally diagnostic microfossil groups such as dinocysts, radiolarians, ostracods, fish debris, bryozoans, small corals, and inoceramid prisms were also made for all core catcher samples. Calcareous nannofossil and planktonic foraminiferal events form the chronologic framework for Site U1513 shallower than $450 \mathrm{~m}$ CSF-A.

Stratigraphic positions of calcareous nannofossil biozones and age assignments for Site U1513 are presented in Figure F5. Abundant planktonic foraminifers and calcareous nannofossils form the biostratigraphic framework of Site U1513 and indicate recovery of Pleistocene to Miocene strata unconformably overlying a lowermost Campanian to Albian sequence. Preservation of nannofossils is good to excellent throughout the sequence, and preservation of planktonic foraminifers varies throughout the sequence from very poor to excellent, with samples showing minimal or no evidence of recrystallization at several intervals in the Cretaceous. Sediments sampled from deeper than $372 \mathrm{~m}$ CSF-A are predominantly barren of planktonic and benthic foraminifers, and samples from deeper than $437 \mathrm{~m}$ CSF-A are barren of calcareous nannofossils.
Benthic foraminifers indicate a bathyal water depth throughout Site U1513 and are dominated by calcareous taxa above the middle Turonian and by agglutinated taxa in lower Turonian through upper Albian samples.

\section{Paleomagnetism}

The NRMs of all archive-half core sections and 98 discrete samples collected from the working halves of Holes U1513A, U1513B, U1513D, and U1513E were measured. The archive halves were stepwise treated with up to 20 or $30 \mathrm{mT}$ AF demagnetization and measured with the pass-through SRM at $5 \mathrm{~cm}$ intervals. Discrete samples were progressively demagnetized up to 60 or $80 \mathrm{mT}$ and measured with the spinner magnetometer or the SRM. The NRM intensity of the recovered cores is $10^{-5}$ to $1 \mathrm{~A} / \mathrm{m}$ and broadly co-varies with lithology. The calcareous ooze and chalk in the upper part and the basalt in the basal part of Hole U1513D display the weakest and the strongest NRM intensity, respectively. Despite the weak NRM of the calcareous ooze/chalk, the demagnetization results after $20 \mathrm{mT}$ show inclination zones of dominant positive and negative values, defining a magnetic polarity sequence from Chron C1n to Chron C2An.3n for the uppermost $\sim 65 \mathrm{~m}$. The inclinations in the 65-455 m CSF-A interval are mostly scattered, and dominant negative values from 200 to $450 \mathrm{~m}$ CSF-A indicate a normal polarity that is assigned to Chron C34n based on shipboard biostratigraphy. The inclinations deeper than $455 \mathrm{~m}$ CSF-A exhibit a distinct pattern of zones of either positive or negative values, establishing a well-defined magnetic polarity sequence (Figure F5). The polarity sequence between 455 and $\sim 690 \mathrm{~m}$ CSF-A is tentatively correlated with Chrons M0r-M10n, indicating the absence of most of the Aptian strata and increasing sedimentation rates between $\sim 530$ and $\sim 690 \mathrm{~m}$ CSF-A. The well-defined reversed and normal polarities deeper than $\sim 690 \mathrm{~m}$ CSF-A occur in the basalt unit and cannot be correlated with the geomagnetic polarity timescale (GPTS) without constraints of ages from the basalt.

\section{Petrophysics}

Physical property data were obtained with the WRMSL, NGRL, PWC, and SHMSL and on discrete samples. Cores from the uppermost 35 m exhibit cyclicity in NGR ( $\sim 15$ counts/s amplitude; $\sim 5 \mathrm{~m}$ thickness), and the measurements were deconvolved into $U, T h$, and $\mathrm{K}$ concentrations. The $\mathrm{C} / \mathrm{T}$ boundary interval shows a distinct NGR plateau of $\sim 40$ counts/s at $\sim 240-245$ m CSF-A. Additionally, NGR values preserve a broad trend to higher counts throughout a mudstone interval spanning from 230 to $455 \mathrm{~m} \mathrm{CSF-A} \mathrm{with} \mathrm{a}$ trough near 320 m CSF-A (Figure F5). Below a contact with underlying volcaniclastic sandstone at $455 \mathrm{~m}$ CSF-A, NGR decreases by nearly an order of magnitude from 75 to 10 counts/s, and magnetic susceptibility increases by two orders of magnitude from $\sim 10$ to $\sim 1000$ IU. Similarly, both grain and bulk density step to higher values across this transition. NGR values, more specifically U content, spike across an interval near $675 \mathrm{~m}$ CSF-A, possibly signifying abundant terrestrial organic matter. The indurated breccia and crystalline rocks in lithostratigraphic Unit VI show spikes in magnetic susceptibility and density and have nearly undetectable NGR counts. In the overlying sedimentary sequence (Units I-V), porosity and PWC measurements show a generally gradual but punctuated change to lower and higher values, respectively.

Downhole logging was conducted in Holes U1513A, U1513D, and U1513E using several downhole tool configurations, including the Quambo, which measures NGR, density, sonic velocity, and resistivity; the traditional triple combo; the Formation MicroScanner 
Figure F5. Site U1513 summary. Recovery and data from Hole U1513E are not included, but data are consistent with the bottom of Hole U1513D. Hole U1513C $(\sim 17 \mathrm{~m})$ was sampled completely on the catwalk. NGR: green $=$ Hole U1513A, light blue $=$ Hole U1513B, dark blue $=$ Hole U1513D, yellow shading $=$ seaflooranchored and floating spliced intervals. RGB green: dark green data curve $=50$-point moving average. See Table T5 and T6 in the Site U1513 chapter (Huber et al., 2019b) for calcareous nannofossil and planktonic foraminifer event definitions.

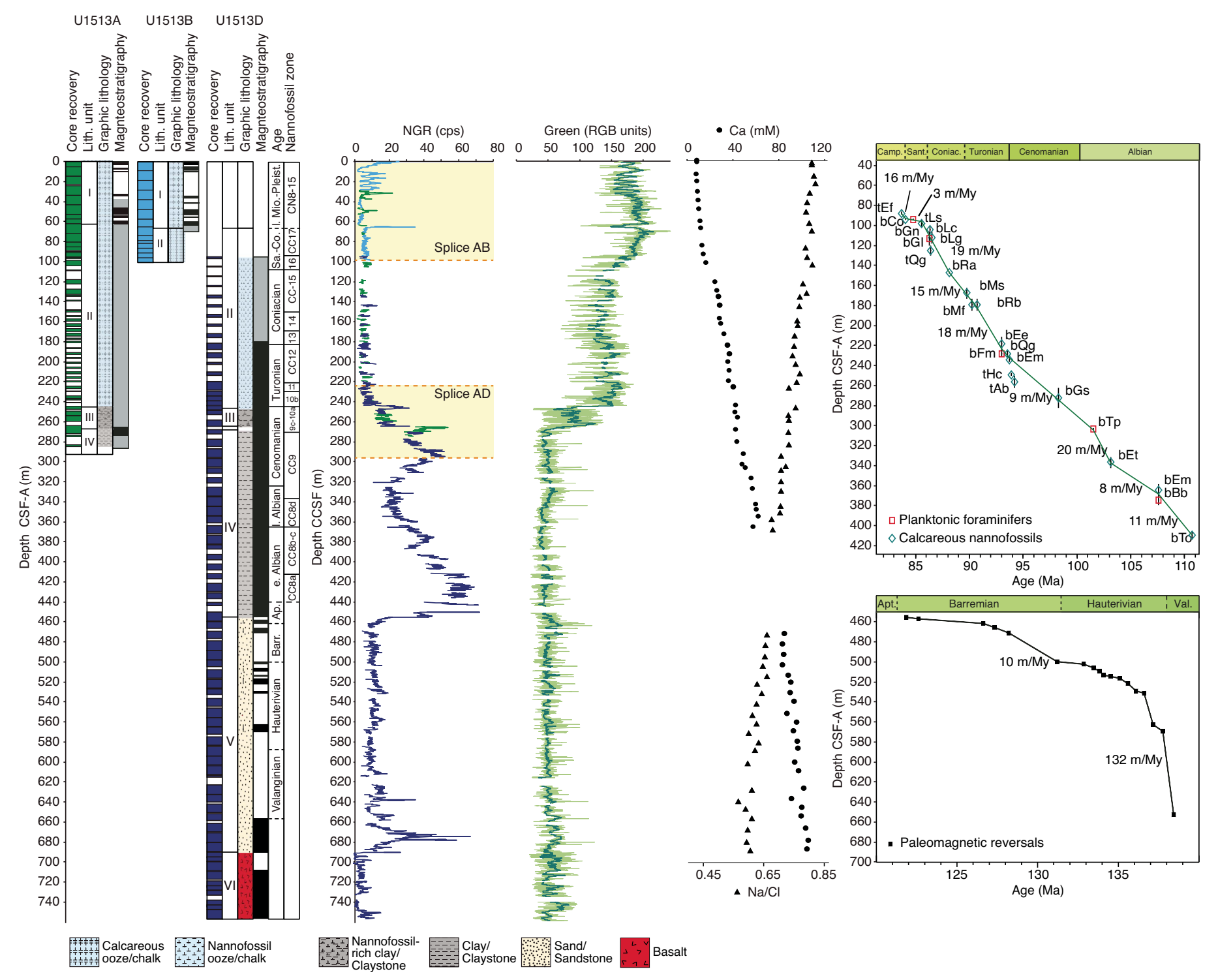

(FMS) with the porosity tool; and the Vertical Seismic Imager for some intervals in Hole U1513E. NGR, density, and resistivity measurements from each hole yielded similar results for the overlapping depth intervals across Holes U1513A, U1513D, and U1513E. The most continuous downhole logging run using the triple combo occurred in Hole U1513E and spanned from a bridge at $\sim 615 \mathrm{~m}$ WMSF to the bottom of the drill pipe at $119 \mathrm{~m}$ WMSF. The wireline logging data provided continuous coverage and filled several coring gaps. The most striking features observed include a strong positive response in resistivity, density, and sonic velocity values through intervals of silicified limestone (96-123 and 152-180 m WMSF; lithostratigraphic Unit II) and a shift from low to high NGR across the C/T boundary interval ( 240-245 m WMSF). NGR increases downhole from this horizon through the Cenomanian to Albian claystones, displaying similar trends to the core-based NGR. In situ temperature measurements were attempted in Hole U1513B, but this experiment returned only one reliable measurement of $4.55^{\circ} \mathrm{C}$ from Core $5 \mathrm{H}$.

\section{Geochemistry}

The Site U1513 geochemistry program was designed to characterize interstitial water and bulk sediment composition and to assess the potential presence of volatile hydrocarbons for routine safety monitoring. Samples were taken from Holes U1513A and U1513D. All 90 headspace gas samples showed only low concentrations of methane ( $\leq 60 \mathrm{ppmv})$ and trace levels of ethane and propane.

For interstitial water analyses, 60 samples were recovered from squeezing $10 \mathrm{~cm}$ whole rounds from $0-366.4$ and $471.8-687.3 \mathrm{~m}$ CSF-A. Salinity was generally constant, with the exception of distinctly fresher interstitial water between 281.8 and $303.0 \mathrm{~m}$ CSFA. This interval of low salinity is also apparent in the $\mathrm{Br}^{-}$and $\mathrm{Cl}^{-}$ profiles. $\mathrm{Mg}, \mathrm{K}$, and $\mathrm{Na}$ concentration profiles reflect the alteration 
of volcanic material found in lithostratigraphic Units IV and V. No evidence for significant sulfate reduction was detected; sulfate is present in all samples, and $\mathrm{Ba}$ concentrations are correspondingly low. Ca (Figure F5) and Sr concentration profiles primarily reflect the release of these elements during alteration of volcanic material. $\mathrm{Li}$ appears to have been released in Unit IV and then incorporated into alteration products in Unit V. Dissolved Si reflects the presence of biogenic opal-A in Units I and II; lower concentrations in Units III and V may reflect the opal-A/CT and CT to quartz transitions, respectively. Elevated $\mathrm{Mn}$ concentration demonstrates the reducing character of the sedimentary sequence below Unit I.

In addition, 129 bulk sediment samples were collected downhole to $\sim 690 \mathrm{~m}$ CSF-A (Core 369-U1513D-65R), the contact with igneous material. Additional samples were measured at a higher resolution through the putative OAE 2 and $1 \mathrm{~d}$ intervals (between Sections 17R-4 and 19R-CC; black shales with high TOC between 246.32 and $247.34 \mathrm{~m}$ CSF-A). $\mathrm{CaCO}_{3}$ content varies from 0 to $93 \mathrm{wt} \%$, reflecting variations in lithology. TOC is broadly $<1 \mathrm{wt} \%$ except in the thin black shales, where TOC reaches $10.5 \mathrm{wt} \%$. TN is generally below detection. A total of 57 samples with TOC $\geq 0.8 \mathrm{wt} \%$ from the possible OAE 2 and 1d intervals were analyzed with the source rock analyzer. Samples with a higher TOC content (>3 wt\%) were found to contain dominantly marine organic matter, whereas the source of the organic matter in low-TOC samples could not be determined.

\section{Stratigraphic correlation}

Recovery in any one hole at Site U1513 ranged from poor to excellent, but when combined, overall recovery was excellent for most of the interval that penetrated and spanned the Valanginian through the present day. Splices were constructed for the 0-95 m core composite depth below seafloor (CCSF) intervals (Holes U1513A and U1513B) and for the 220-295 m CCSF intervals (Holes U1513A and U1513D) (Figure F5). These splices cover the late Miocene through recent and the middle Cenomanian through middle Turonian, respectively, as estimated from bio- and magnetostratigraphy. Portions of both splices were formed by appending subsequent cores from the same hole because of aligned core breaks or poor recovery in the other hole (i.e., there was no bridge across core breaks in these intervals). However, correlation to downhole logging data minimized the uncertainty introduced by this approach. The 95$220 \mathrm{~m}$ CSF-A interval was recovered in Holes U1513A and U1513D. Despite this, no splice was attempted in this interval because recovery was too low to meaningfully correlate at the meter scale, but pooled data suggest recovery should be sufficient to generate good records with $1 \mathrm{My}$ resolution. The interval from 295 to $757.4 \mathrm{~m}$ CSF-A was only cored in Hole U1513D, but recovery was generally very good to excellent, averaging $82 \%$ across $\sim 70 \mathrm{~m}$ of basalt and basaltic breccia (lithostratigraphic Unit VI) and 75\% over the $395 \mathrm{~m}$ of overlying sandstones and claystones (Unit V) between the basalt and the lower splice. The oldest biostratigraphic date for these overlying sediments is middle Albian, although magnetostratigraphy suggests portions could be older.

\section{Age-depth model and sedimentation rates}

Sedimentation rates are presented in Figure F5 for the Albian through Campanian portion of Site U1513. Sedimentation rates averaged $\sim 12 \mathrm{~m} /$ My from the Albian through Coniacian but dropped appreciably during the Santonian and lower Campanian to only $8 \mathrm{~m} / \mathrm{My}$, with an apparent rate of only $3 \mathrm{~m} / \mathrm{My}$ in the Santonian. Alternatively, part of the Santonian may be missing due to a hiatus in sediment accumulation. Sediment accumulation rates deeper than $450 \mathrm{~m}$ CSF-A are based on the paleomagnetic record. Sedimentation rates for the Barremian to upper Hauterivian (Chron M0 to the base of Chron Mr8) averaged approximately $10 \mathrm{~m} / \mathrm{My}$, whereas estimated rates for the lower Hauterivian and Valanginian (Chron M9 to Chron M10) are $132 \mathrm{~m} / \mathrm{My}$.

\section{Site U1514}

\section{Background and objectives}

Site U1514 (Table T1) is the northernmost and deepest site targeted during Expedition 369. The greater paleodepth of the site relative to other sites cored in the Mentelle Basin provides the opportunity to characterize the evolution of deep-water circulation in this region during the final phase of breakup among the Gondwana continents. Because Site U1514 is located at a high paleolatitude $\left(\sim 60^{\circ} \mathrm{S}\right)$, the sediments there preserve a paleoclimate record that serves as a highly sensitive monitor of global climatic changes. The site was expected to sample a series of Cenozoic and possibly Late Cretaceous sedimentary drifts and erosional features that would enable greater insight into the early and later phases of the opening of the Tasman Gateway and restriction of the Indonesian Gateway. The current seabed is composed of Paleogene/Neogene/Quaternary oozes that sit unconformably on the Cretaceous (Maloney et al., 2011).

The primary objectives for coring Site U1514 were to (1) obtain a continuous Cenozoic sediment record in the Mentelle Basin to characterize how oceanographic conditions changed during the Cenozoic opening of the Tasman Gateway and the restriction of the Indonesian Gateway; (2) reconstruct middle through Late Cretaceous paleotemperature changes to document initiation of the Cretaceous hot greenhouse climate, the duration of extreme warmth, and the timing of the switch to a cooler climate; and (3) obtain a complete and well-preserved sediment record across mid-Cretaceous OAEs to better understand their cause and accompanying changes in the climate-ocean system and the marine biota.

\section{Lithostratigraphy}

The Site U1514 cored section is divided into three main lithostratigraphic units based on data from Holes U1514A and U1514C, and Units I and III are further divided into two subunits (Figure F6). Lithostratigraphic units and boundaries are defined by changes in lithology identified by macroscopic core description, microscopic examination of smear slides, and XRD and XRF analyses.

Lithostratigraphic Unit I is a $81.20 \mathrm{~m}$ thick Pleistocene to Eocene sequence of very pale brown to pale yellow nannofossil ooze, foraminiferal ooze, and sponge spicule-rich nannofossil ooze that is Pliocene to Pleistocene in age. The unit is divided into Subunits Ia and Ib at $30.38 \mathrm{~m}$ CSF-A in Hole U1514A. Subunit Ib spans the Miocene to Eocene and differs from Subunit Ia by an increased abundance of sponge spicules. Furthermore, the color of Subunit Ib is yellow-brown and distinctively darker than Subunit Ia. Unit II is a $308.01 \mathrm{~m}$ thick Eocene to Paleocene sequence of light greenish gray clayey nannofossil ooze, sponge spicule-rich clay, and nannofossilrich clay that grades into clayey nannofossil chalk and nannofossilrich claystone. Unit III is a $126.43 \mathrm{~m}$ thick sequence of greenish gray, brown, and black claystone that is Paleocene to Albian in age. Unit III is divided into Subunits IIIa and IIIb at $454.33 \mathrm{~m}$ CSF-A in Hole U1514C. Subunit IIIb was deposited during the Cenomanian/Albian to Albian and is distinguished from overlying Subunit IIIa (Paleocene to Cenomanian/Albian) in that it is a darker greenish gray/black claystone. Soft-sediment deformation, possibly including 
Figure F6. Site U1514 summary. Hole U1514B ( 15 m) was sampled completely on the catwalk. NGR and carbonate: blue = Hole U1514A, green = Hole U1514C. Yellow shading $=$ floating spliced interval. See the Site U1514 chapter (Huber et al., 2019c) for additional details.

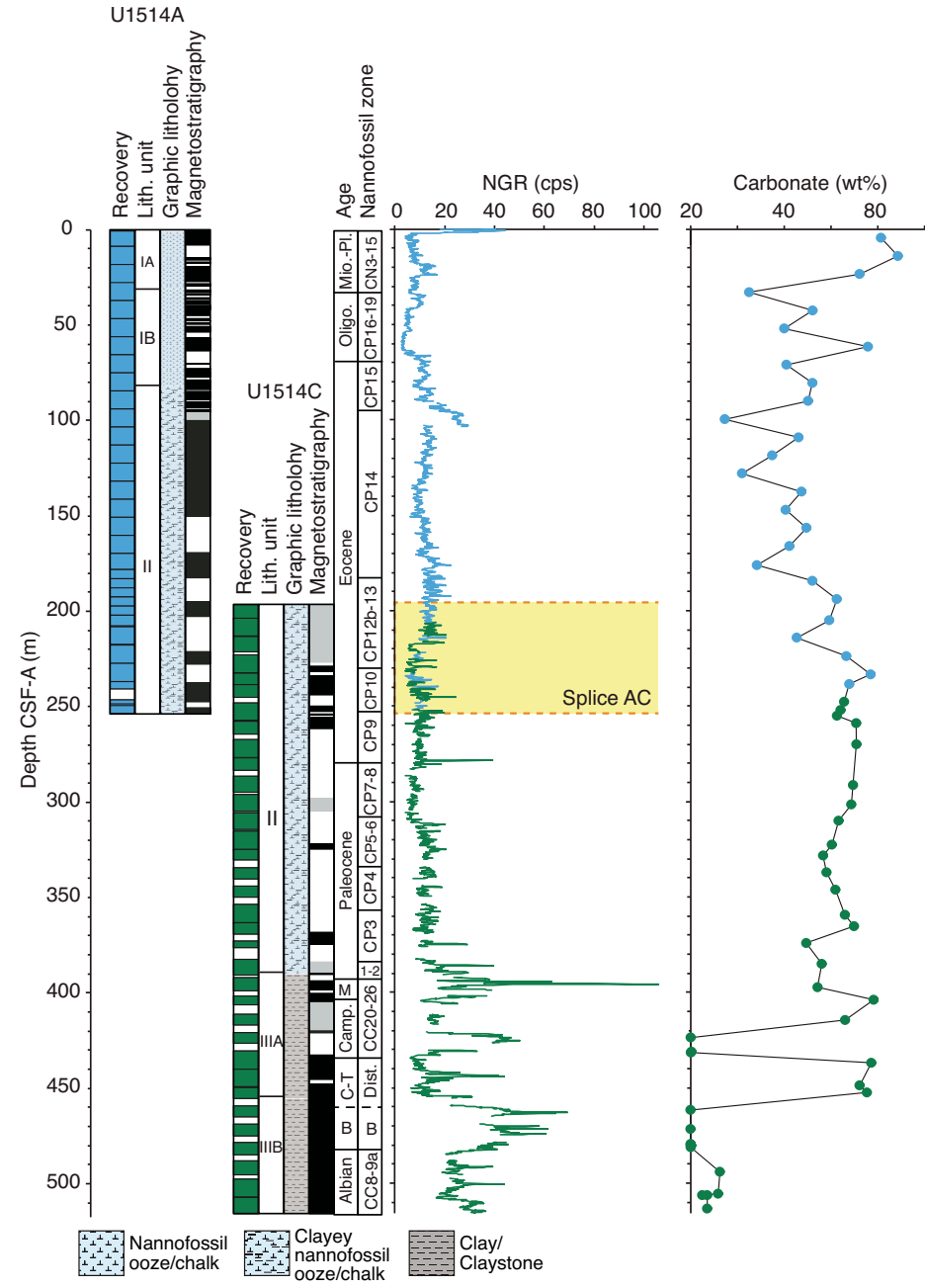

slumping, is indicated by intervals of convoluted and overturned bedding in Subunits IIIa and IIIb.

\section{Biostratigraphy and micropaleontology}

Samples from core catchers in Holes U1514A and U1514C were analyzed for calcareous nannofossils, planktonic foraminifers, and benthic foraminifers. As necessary, additional samples from splitcore sections were evaluated for calcareous nannofossils and/or planktonic foraminiferal assemblages. Observations of other distinctive and potentially age or environmentally diagnostic microfossil groups, including calcispheres, diatoms, radiolarians, fish debris, sponge spicules, and inoceramid prisms, were also recorded.

Stratigraphic positions of calcareous nannofossil biozones and age assignments for Site U1514 are presented in Figure F6. Calcareous nannofossils occur throughout the succession cored at Site U1514, except for a few barren samples in the Cenomanian to early Turonian. Specimens are moderately to well preserved throughout. Planktonic foraminiferal assemblages recovered at Site U1514 are generally rare, with poor to moderate preservation, although discrete samples in the Pleistocene, Paleocene, Turonian, and Albian contain seemingly unrecrystallized specimens. Planktonic foraminiferal assemblages in Hole U1514A span Pleistocene Subzone Pt1a through lower Eocene Zone E4. Assemblages in Hole U1514C range

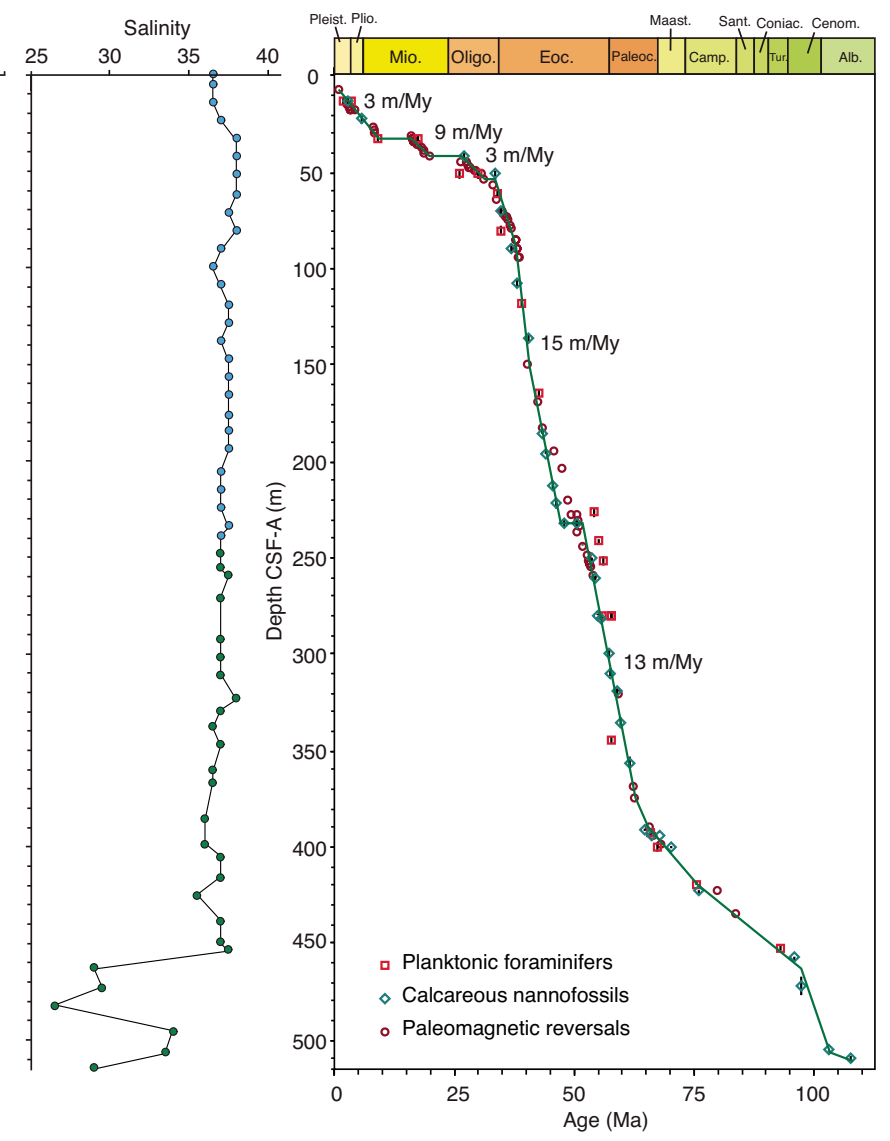

from middle Eocene Zones E8-E9 to the Thalmanninella appenninica/Pseudothalmanninella ticinensis Zones of the upper Albian. An apparently complete (at least to biozone level) though bioturbated Cretaceous/Paleogene $(\mathrm{K} / \mathrm{Pg})$ boundary section was recovered in Core 369-U1514C-23R.

Benthic foraminiferal assemblages are dominated by epifaunal, calcareous-walled taxa that indicate bathyal to abyssal paleowater depths throughout the recovered interval.

\section{Paleomagnetism}

The NRMs of all archive-half core sections and 82 discrete samples collected from the working halves in Holes U1514A and U1514C were determined as part of the paleomagnetism measurement program (Figure F6). The archive halves were stepwise treated with up to 20 or $30 \mathrm{mT}$ AF demagnetization and measured with the pass-through SRM at $5 \mathrm{~cm}$ intervals. Discrete samples were progressively demagnetized up to $60 \mathrm{mT}$ and measured with the SRM. The NRM intensity of the recovered cores is $10^{-6}$ to $1 \mathrm{~A} / \mathrm{m}$ and broadly co-varies with lithology. Inclinations after the $20 \mathrm{mT}$ demagnetization step exhibit intervals dominated by positive and negative inclination values, defining an almost complete magnetic polarity sequence with 74 identified and dated reversals from Chron C1n (Brunhes) to Chron C34n (the CNS). The magnetic data are of 
excellent quality in the advanced piston corer section (0-95 m CSFA) and exhibit larger scatter caused by drilling disturbance in the extended core barrel and RCB cores. The sequence is interrupted by four hiatuses $(11,18,30$, and $41 \mathrm{~m}$ CSF-A) placed at sharp lithologic boundaries and confirmed by biostratigraphic observations.

\section{Petrophysics}

Magnetic susceptibility, GRA bulk density, NGR, thermal conductivity, $P$-wave velocity, color reflectance spectroscopy and colorimetry (RSC), and MAD were measured on whole-round sections, split core sections, and discrete samples from Site U1514. Several unique features were identifiable using the physical property data (Figure F6). Notable features include distinct signals in the NGR, magnetic susceptibility, and GRA bulk density data near the Chron C19r event ( 152 m CSF-A), the Paleocene to Eocene interval ( 275-280 $\mathrm{m}$ CSF-A), the K/Pg boundary (382-415 m CSF-A), and the Cenomanian to Turonian interval (415-445 m CSF-A). However, the Cenomanian to Turonian interval is within a zone of extensive sediment deformation and is unlikely to reflect paleoceanographic events.

Magnetic susceptibility varies between 1.76 and $50.48 \mathrm{IU}$, and measurements consist of sections of high- and low-frequency variations downhole. GRA bulk density ranges from 1.6 to $1.9 \mathrm{~g} / \mathrm{cm}^{3}$. NGR ranges from 0 to 105 counts/s with high-amplitude cyclic fluctuations downhole that are coincident with changes in sediment RSC. The bulk density, grain density, and porosity of cored material were measured on discrete samples (MAD). These data show several deviations from the expected trend. In several sections, porosity increases with depth. These increases may reflect lithologic changes and/or be associated with soft-sediment deformation that may have led to several packages of material being more over- or undercompacted than the surrounding beds. $P$-wave velocity ranges from $\sim 1500 \mathrm{~m} / \mathrm{s}$ near the seafloor to $\sim 2100 \mathrm{~m} / \mathrm{s}$ at $\sim 290 \mathrm{~m} \mathrm{CSF-A.}$ Velocity tends to decrease below this depth to $1800-1900 \mathrm{~m} / \mathrm{s}$ at the bottom of the hole (515.7 m CSF-A), except for the 390-470 m CSFA interval, where velocities are scattered between 1800 and $2300 \mathrm{~m} / \mathrm{s}$. The latter interval spans the zone with soft-sediment deformation.

Downhole logging was conducted in Hole U1514C using the Quambo tool string. The measurements yielded similar results for the overlapping depth intervals where core recovery was good. The downhole tools provided continuous coverage of the borehole and filled several coring gaps. The most striking features include several peaks in NGR at $\sim 395, \sim 425$, and $445 \mathrm{~m}$ WMSF and between 455 and $480 \mathrm{~m}$ WMSF. Interestingly, the two peaks in the NGR log at $\sim 395$ and $\sim 425 \mathrm{~m}$ WMSF correspond to a decrease in bulk density, sonic velocity, and resistivity, as well as more clay rich lithofacies. Slower sonic velocities are also notable between 420 and $440 \mathrm{~m}$ WMSF, which could (at least partially) reflect a thick zone of softsediment deformation. Magnetic susceptibility data were collected in Hole U1514C, but the signal quality was poor. In addition, in situ temperature measurements were obtained in Hole U1514A and were combined with the thermal conductivity data to determine a heat flow of $45-49 \mathrm{~mW} / \mathrm{m}^{2}$.

\section{Geochemistry}

The Site U1514 geochemistry program was designed to characterize the composition of interstitial water and bulk sediments and to assess the potential presence of volatile hydrocarbons for routine safety monitoring. Samples were taken from Holes U1514A and $\mathrm{U} 1514 \mathrm{C}$. A total of 56 headspace gas samples were taken, with only low concentrations of methane ( $\leq 90 \mathrm{ppmv})$ and trace levels of ethane detected.

For interstitial water analyses, 54 samples were recovered from whole-round squeezing of samples from sediment intervals in Holes U1514A (0-247.7 m CSF-A) and U1514C (255.0-515.7 m CSF-A). Sample salinity is generally constant, with the exception of distinctly fresher interstitial water in lithostratigraphic Subunit IIIa (Figure F6). This low-salinity interval reflects decreased concentrations of many elemental profiles, particularly $\mathrm{Br}^{-}$and $\mathrm{Cl}^{-}$. $\mathrm{Mg}, \mathrm{K}, \mathrm{Ca}, \mathrm{Li}, \mathrm{Sr}$, and $\mathrm{Na}$ concentration profiles reflect alteration of volcanic material from depths below the cored interval at Site U1514. Moderate sulfate reduction was inferred because sulfate is present but decreases with depth. Ba concentrations are correspondingly low. Si concentrations reflect the presence of biogenic opal-A in Units I and II and the top part of Subunit IIIa; lower concentrations at the bottom of Subunit IIIa and in Subunit IIIb may reflect the opal-A/CT transition. Elevated $\mathrm{Mn}$ and Fe concentrations demonstrate the reducing character of the sedimentary sequence at certain intervals at this site.

A total of 64 bulk sediment samples were collected downhole to $\sim 513$ m CSF-A (Core 369-U1514C-35R). $\mathrm{CaCO}_{3}$ content varies from 0 to $90 \mathrm{wt} \%$, reflecting variations in lithology (Figure F6). TOC is generally $<0.3 \mathrm{wt} \%$ except in the possible OAE $1 \mathrm{~d}$ interval, where TOC reaches $1.2 \mathrm{wt} \%$. TN is generally below detection. A total of 8 working-half samples from the disturbed interval that likely spanned the Turonian and Cenomanian and possible OAE 1d interval (Cores 32R-34R) were analyzed on the source rock analyzer. Although the lower TOC content samples were generally inconclusive, kerogen in samples with higher TOC content (>1 wt\%) were found to have a dominantly terrestrial source.

\section{Stratigraphic correlation}

Recovery in Hole U1514A was excellent (near 100\%), and the total recovery of Holes U1514A and U1514C was 65\%. Target depths were recommended before and during the coring of Hole U1514C, which aided the bridging of coring gaps in Hole U1514A. A splice was created for the overlapping portion of the lower Eocene, spanning from 195.6 to $266.1 \mathrm{~m}$ CCSF in Holes U1514A and U1514C. This splice was established by identifying similar trends in NGR and subsequently comparing high-resolution physical property data. Recognition of sharp peaks in NGR enabled correlation of core data to wireline logging results and confirmed the accuracy of the splice.

Together, Holes U1514A and U1514C span from the end of the Albian to the present, with good coverage over much of the Paleogene and Upper Cretaceous, including a seemingly complete record over the K/Pg boundary in Core 369-U1514C-23R. Downhole, a multicolored interval of deformed sediments spanning Cores 25R through $29 \mathrm{R}$ is consistent with the downslope motion of the upper portion of the sequence at this site.

\section{Age-depth model and sedimentation rates}

Sedimentation rates vary throughout the section, with the lowest rates recorded in the Neogene and Cretaceous (3-9 m/My) and the highest rates (13-15 m/My) recorded in the Eocene and Paleocene (Figure F6). Major unconformities are present in the lower Pleistocene, Pliocene, Miocene, and Oligocene.

\section{Site U1515}

\section{Background and objectives}

Site U1515 (Table T1) is the easternmost Mentelle Basin site and shallowest site targeted during Expedition 369. The primary objective at this site was to provide evidence of the prebreakup 
Figure F7. Site U1515 summary. Red wavy line = unconformity inferred from seismic and physical property data. See the Site U1515 chapter (Huber et al., 2019d) for additional details.

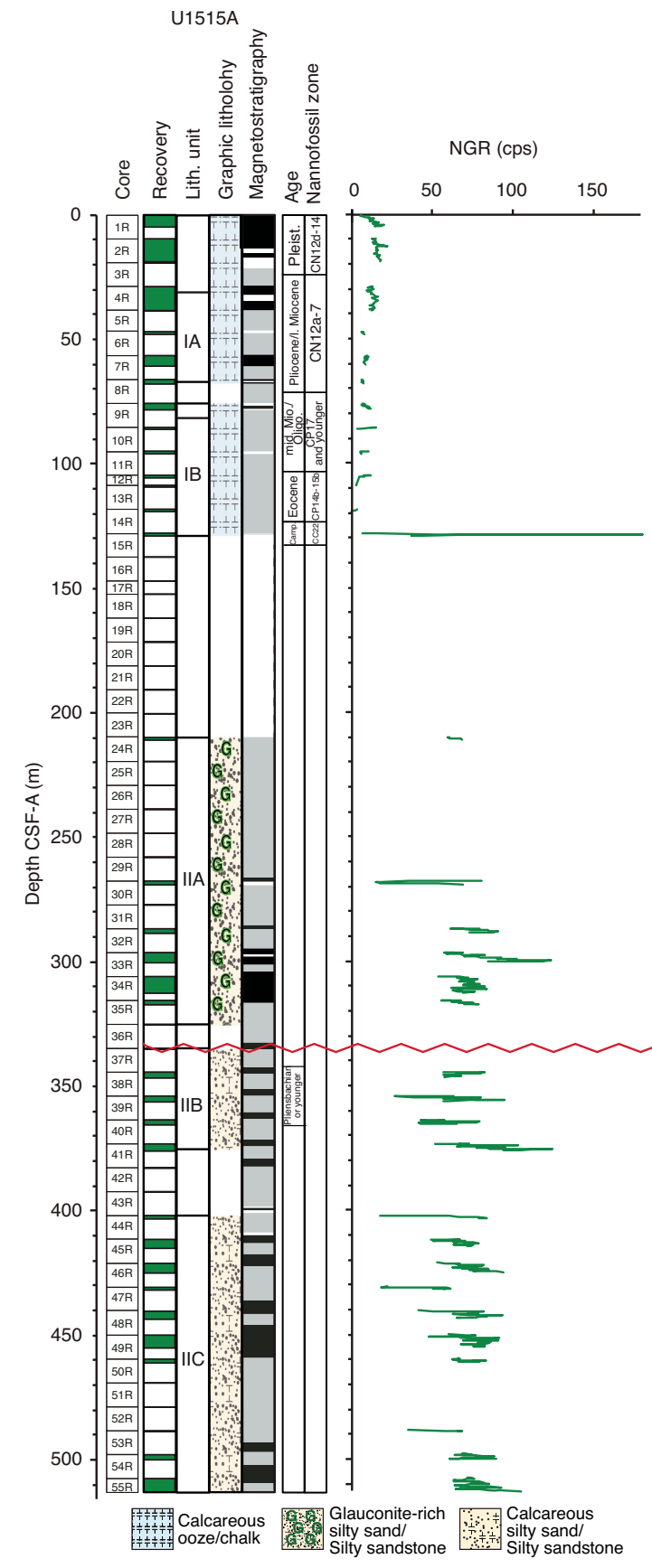

rifting history in the region prior to the final separation of Greater India and Antarctica. The site location was chosen based on seismic evidence of dipping strata below what is interpreted to be the eastward extension of the Valanginian unconformity cored at Site U1513 in the western Mentelle Basin. The extrusive basalts that cover this unconformity in the western Mentelle Basin are not present at Site U1515.

Structural interpretations suggest that depocenters in the eastern Mentelle Basin are older (Permian? to Jurassic) than those in the western Mentelle Basin (Jurassic?) (Borissova et al., 2002). Site U1515 is the first site to sample this eastern depocenter and will test hypotheses concerning early Mesozoic rifting. Cores recovered
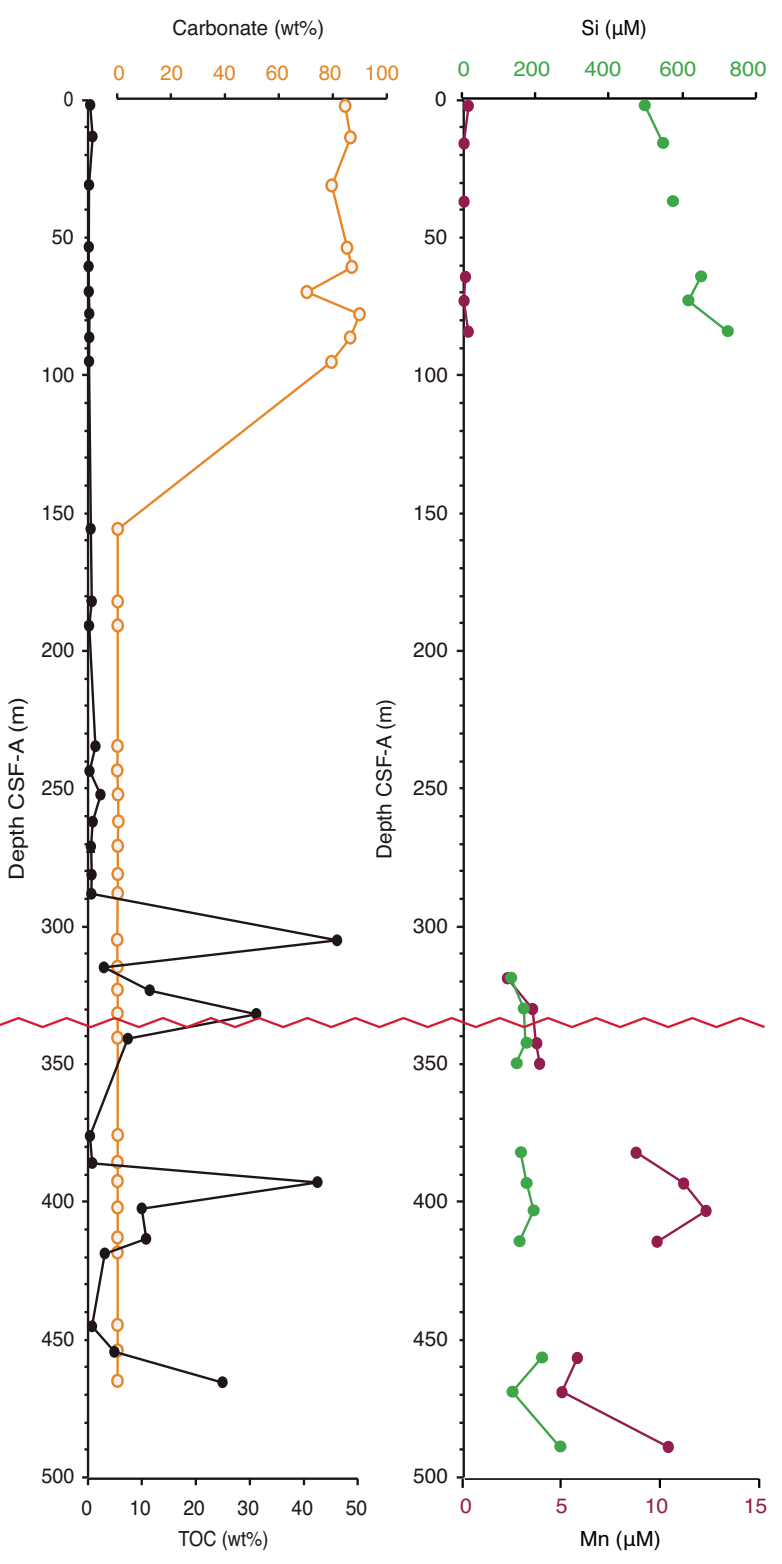

from this site will enable investigation of the tectonic and structural relationships with similarly aged rifts along the western margin of Australia, in particular the adjacent Perth Basin (Bradshaw et al., 2003), and rift structures in Antarctica (Maritati et al., 2016). Finally, the cored record will ascertain the provenance of the earlier (Jurassic?) sediments. Candidates include the Pinjarra orogen or Albany-Frazer province.

\section{Lithostratigraphy}

The cored section in Hole U1515A, the only hole at Site U1515, is divided into two main lithostratigraphic units (I and II; Figure F7), which are further divided into five subunits (Ia, Ib, and IIa-IIc). 
Lithostratigraphic units and boundaries are defined by changes in lithology identified by macroscopic core description, microscopic examination of smear slides and thin sections, and XRD and XRF analyses. Unit thicknesses are not given because of the overall low core recovery. Lithostratigraphic Unit I (Cores 369-U1515A-1R through 15R) is a sequence of calcareous ooze/chalk with sponge spicules, silicified limestone, bioclastic limestone, chert, sandy limestone, and sandstone (arkose). Subunit Ia (Cores 1R through 8R) consists of light greenish gray calcareous ooze with sponge spicules, whereas Subunit Ib (Cores 9R through 15R) is generally more lithified and consists largely of calcareous chalk and 10-40 cm thick silicified limestone with frequent chert beds. Because of poor recovery in this interval, the contact between Units I and II was not recovered. Unit II (Cores 24R through 55R) largely consists of gray to black silty sand and glauconitic sandstone/silty sandstone. Subunit IIa (Cores 24R through 36R) is characterized by abundant glauconite and consists of black to greenish gray silty sand and sandstone. Subunit IIb (Cores 37R through 41R) consists largely of fine- to coarse-grained sandstone with interbedded siltstone and claystone. This subunit differs from Subunit IIa in that it contains less glauconite and more abundant pyrite nodules. Subunit IIb grades into organic-rich silty sandstone and claystone with coal and plant debris, which are characteristic components of Subunit IIc (Cores 44R through 55R). The sediments recovered in Unit II are possibly terrestrial in origin.

\section{Biostratigraphy and micropaleontology}

Hole U1515A core catcher samples were analyzed for calcareous nannofossils, planktonic foraminifers, and benthic foraminifers. Observations were recorded for other distinctive and potentially age or environmentally diagnostic microfossil groups, including calcispheres, radiolarians, pollen grains and spores, fish debris, sponge spicules, and inoceramid prisms.

Microfossils occur in the upper part of the hole (Cores 369U1515A-1R through 15R), whereas the lower part (Cores 16R through 49R; no samples were taken below Core 49R) is barren of all calcareous and siliceous microfossil groups. However, a spore found in a smear slide of Sample 39R-1, $97 \mathrm{~cm}$, was identified as Contignisporites sp. (likely Contignisporites glebulentus), which could indicate a Pliensbachian age or younger. Most of the Neogene and Paleogene samples (Cores 1R through 14R) indicate reworking of Pliocene, Miocene, Oligocene, and Eocene species. The nannofossil biostratigraphy in Hole U1515A spans from upper Pleistocene Subzone CN14b to upper Campanian Zone CC22. Planktonic foraminiferal assemblages are in good agreement with this stratigraphic determination, spanning from upper Pleistocene Subzone Ptlb through the late Campanian/late Santonian Globigerinelloides impensus Zone. Benthic foraminiferal assemblages indicate an outer neritic to upper bathyal paleodepth throughout the analyzed interval (Figure F7).

\section{Paleomagnetism}

The NRMs of most of the archive-half core sections and 19 discrete samples collected from the working halves of Hole U1515A were determined (Figure F7). The archive halves were stepwise treated with up to $20 \mathrm{mT}$ AF demagnetization and measured with the pass-through SRM at $5 \mathrm{~cm}$ intervals. Discrete samples were progressively demagnetized up to $60 \mathrm{mT}$ and measured with the SRM. The NRM intensity of the recovered cores is $10^{-5}$ to $1 \mathrm{~A} / \mathrm{m}$ and broadly co-varies with lithology. Inclinations after the $20 \mathrm{mT}$ demagnetization step exhibit intervals dominated by positive and neg- ative inclinations, defining a brief magnetic polarity sequence from Chron C1n (Brunhes) to Subchron C1r.2r. Although the magnetic record is noisy and the core recovery is poor, intervals of predominantly normal and reversed polarity can be discerned in the remainder of the sections deeper than $20 \mathrm{~m}$ CSF-A. However, a correlation to the GPTS is not possible, mainly because of the poor core recovery and the lack of biostratigraphic control.

\section{Petrophysics}

Site U1515 had low core recovery (18\%), so physical property data are sparse and discontinuous, particularly between $\sim 130$ and $\sim 270 \mathrm{~m}$ CSF-A. Despite the quality of the record, the data show very broad trends from the top of the hole to the bottom, and some comparisons can be made between physical property data and lithology, including a general increase in $P$-wave velocity and thermal conductivity that corresponds to a change from unlithified to weakly lithified glauconitic sand, sandstone and interbedded siltstone, and claystone (lithostratigraphic Subunits IIa and IIb) to silty sandstone and claystone with coal and plant debris (Subunit IIc). This change in velocity also corresponds to a 364-373 m CSF-A unconformity identified in seismic images. Other broad trends include an overall increase in thermal conductivity, an increase in bulk and grain densities, and an overall decrease in porosity. The color reflection and bulk density data are noisy, but they show some trends that can be correlated with lithostratigraphic units. Similarly, the NGR (Figure F7) and magnetic susceptibility data also show broad trends and potentially highlight zones where changes in lithology occur (e.g., the highest magnetic susceptibility values, high bulk density, and low NGR at $\sim 270$ m CSF-A correspond to glauconitic sandstone).

\section{Geochemistry}

The Site U1515 geochemistry program was designed to characterize the composition of interstitial water and bulk sediments and to assess the potential presence of volatile hydrocarbons for routine safety monitoring. Effectively, no gas was detected in the 38 headspace gas samples that were taken.

For interstitial water analyses, 17 samples were recovered from whole-round squeezing of sediment samples from intervals at 2.977.1 and 287.8-441.60 m CSF-A. Sampling was restricted due to low core recovery at Site U1515, which limits interstitial water interpretation. Sample salinity is generally constant, and alkalinity generally decreases downhole. $\mathrm{Mg}, \mathrm{K}$, and Ca concentration profiles possibly reflect alteration of volcanic material from depths below the cored interval for this site. Increasing Sr concentration with depth in lithostratigraphic Unit I may indicate carbonate recrystallization. Low levels of sulfate reduction were detected; sulfate is present but decreases with depth. Dissolved Si reflects the presence of biogenic opal-A in Unit I; lower concentrations in Unit II indicate the interval falls below the opal-A/CT transition (Figure F7). Elevated $\mathrm{Mn}$ and Fe concentrations in Unit II demonstrate the reducing character of the sedimentary sequence in that interval.

A total of 33 bulk sediment samples were collected downhole to 511 m CSF-A (Core 369-U1515A-55R). Within the intervals with carbon-rich layers, small chips were taken for analysis. Carbonate content is very high ( 80-90 wt\%) in the upper part but drops to nearly $0 \mathrm{wt} \%$ deeper than $160 \mathrm{~m}$ CSF-A (Figure F7). Lithostratigraphic Subunit IIa and shallower units contain 0-2.4 wt\% TOC, whereas Subunits IIb and IIc contain as much as 46.2 wt\% TOC (likely coal fragments). TN is $<0.05 \mathrm{wt} \%$ in Subunits Ia, $\mathrm{Ib}$, and IIa but exceeds $0.3 \mathrm{wt} \%$ at four horizons in Subunits IIb and IIc, a pattern similar to that of TOC. In most samples with higher 
Figure F8. Site U1516 summary. Hole U1516B $(\sim 16 \mathrm{~m})$ was sampled completely on the catwalk. Light blue $=$ Hole U1516A, green $=$ Hole U1516C, dark blue $=$ Hole U1516D. Yellow shading = floating spliced interval. See the Site U1516 chapter (Huber et al., 2019e) for additional details.

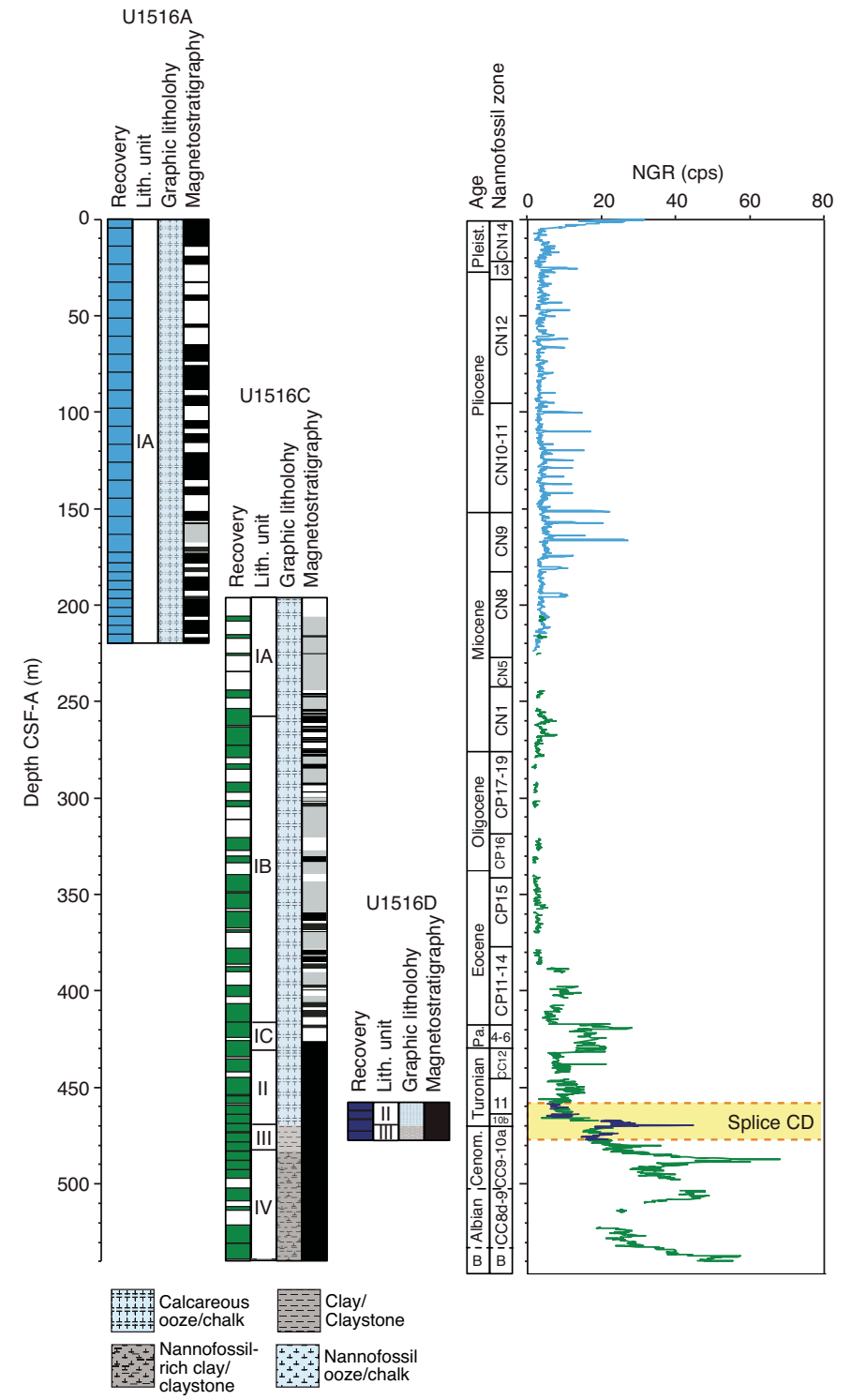

TOC content ( $>1 \mathrm{wt} \%)$, kerogen was found to be predominantly terrestrial in origin, except for the $\sim 430-460 \mathrm{~m}$ CSF-A interval, where a more significant algal contribution is suggested.

\section{Site U1516}

\section{Background and objectives}

Site U1516 (Table T1) is located in the south-central Mentelle Basin. Objectives for drilling at Site U1516 were to (1) obtain a continuous and expanded Cenozoic and Upper Cretaceous pelagic carbonate sediment record in the Mentelle Basin to reconstruct climatic history across the rise and fall of the Turonian and early Eocene hot greenhouse climates, (2) determine the relative roles of productivity, ocean temperature, and ocean circulation in the climate evolution at high southern latitudes during Cretaceous anoxic events; and (3) characterize how oceanographic conditions changed during the Cenozoic opening of the Tasman Gateway and the restriction of the Indonesian Gateway. The Site U1516 sequence will be compared with coeval Expedition 369 sections cored elsewhere
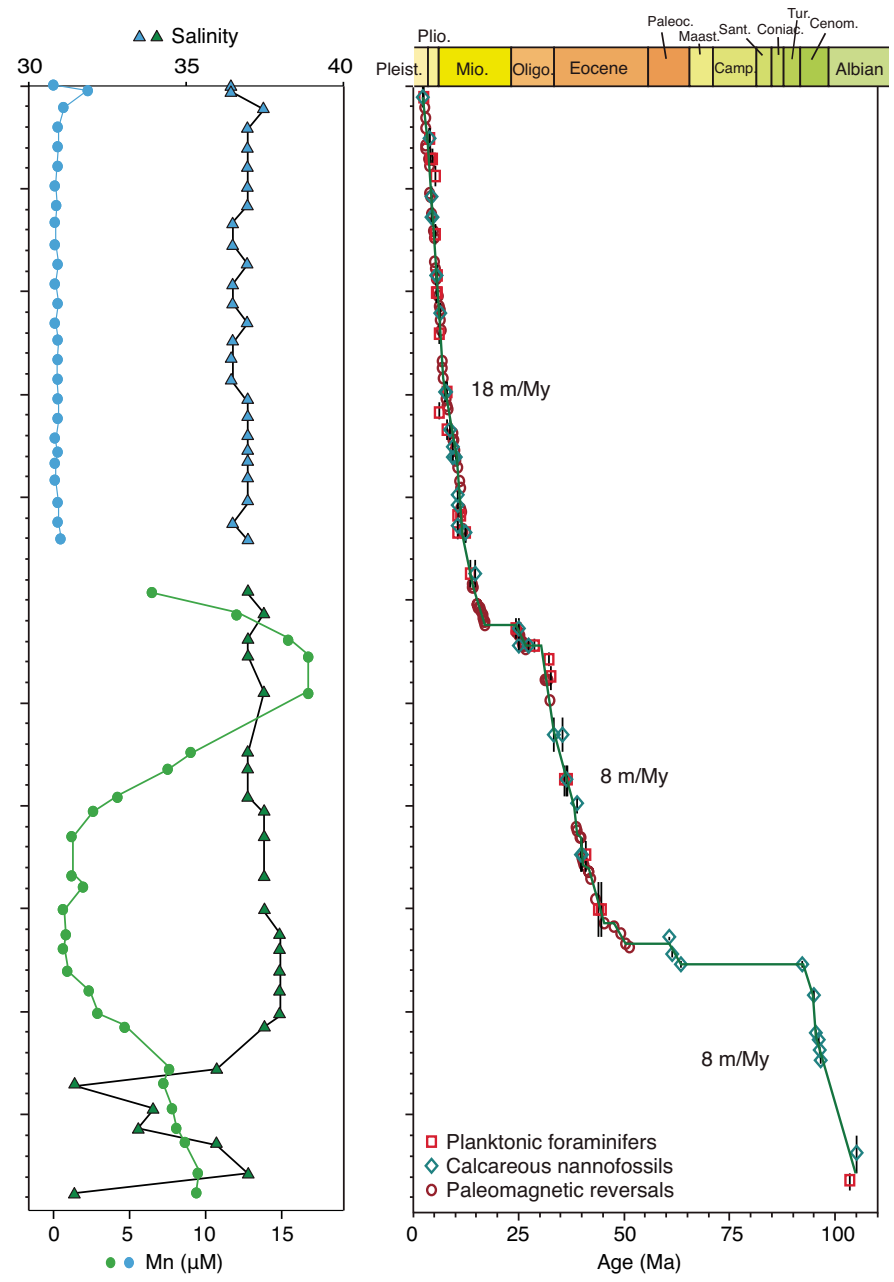

on the Mentelle Basin and with other IODP and industry data from the southern and western Australia margins to correlate recovered lithologies with seismic lines across the Mentelle Basin and to identify regional differences in the geochemical biological responses to the OAEs and Cretaceous, Paleogene, and Neogene ocean circulation history.

\section{Lithostratigraphy}

Site U1516 is divided into four main lithostratigraphic units (IIV; Figure F8), with Unit I divided into three subunits (Ia-Ic). Lithostratigraphic units are defined by changes in lithology identified by macroscopic core description, microscopic examination of smear slides and thin sections, and XRD and XRF analyses. Lithostratigraphic Unit I is a Pleistocene to Paleocene sequence of calcareous/foraminiferal/nannofossil oozes and chalks with sponge spicules. Subunit Ia consists of Pleistocene to Miocene pinkish white, pinkish gray, and very pale orange sponge spicule-rich calcareous oozes. Subunit Ib consists of sponge spicule-rich 
calcareous chalks and calcareous chalks with sponge spicules and spans the Miocene to Eocene. The transition between Subunits Ia and Ib is defined by a shift to higher NGR and bulk density values and a decrease in $L^{*}$ values. Subunit Ic, which is Paleocene in age and consists of claystones, is likely to be a condensed interval. An unconformity between the Paleocene and the Turonian marks the boundary between Units I and II. Unit II is calcareous chalk interbedded with chert and grades into light greenish gray and greenish gray nannofossil chalk with clay that is also interbedded with chert. The boundary between Units II and III is placed at the C/T boundary and is marked by the first occurrence of black laminated claystone at the top of Unit III. Unit III is an alternating sequence of black, greenish gray, and gray claystone (sometimes with abundant nannofossils) and clayey nannofossil chalk with occasional parallel laminations. Unit IV ranges from the Cenomanian to the Albian and is a sequence of black and dark greenish gray nannofossil-rich claystone and claystone with nannofossils that has subtle alternations in color throughout.

\section{Biostratigraphy and micropaleontology}

Coring at Site U1516 recovered a succession of sediments from the Albian through the Pleistocene (Figure F8). Calcareous nannofossils, planktonic foraminifers, and benthic foraminifers occur throughout this succession, and preservation and abundance are sufficient to provide biostratigraphic and paleoecologic information for the entire section.

Calcareous nannofossils are abundant to common throughout the section, with barren samples present only in the middle Albian and associated with the C/T boundary. Preservation is generally good to moderate, with poor preservation associated only with a condensed Paleocene sequence. Reworking of Paleogene taxa into the Neogene assemblages is common. Preservation of planktonic foraminifers is generally good at Site U1516, with some samples in the upper Albian ranked as excellent. Abundance is more variable; the Neogene, Paleogene, and Turonian generally contain abundant planktonic foraminifers, whereas the Albian contains only rare specimens. Benthic foraminiferal abundance and preservation are also variable. In general, examination of benthic foraminifers indicates a bathyal paleodepth during the Albian through Cenozoic.

\section{Paleomagnetism}

We measured the NRM of all archive-half core sections from Holes U1516A, U1516C, and U1516D (Figure F8). The archive halves were stepwise treated with up to $20 \mathrm{mT}$ AF demagnetization and measured with the pass-through SRM at $5 \mathrm{~cm}$ intervals. The NRM intensity of the recovered sedimentary cores is $10^{-6}$ to $10^{-1} \mathrm{~A} / \mathrm{m}$, and lithostratigraphic Unit I, which consists of mainly calcareous oozes and chalk, generally displays weak magnetism. Despite the weak NRM of the calcareous oozes/chalk of Unit I, inclinations after $20 \mathrm{mT}$ demagnetization show zones of dominantly positive and negative values, defining a magnetic polarity sequence with a total of 84 identified and dated reversals for the upper $\sim 430$ $\mathrm{m}$ interval that spans Chrons $\mathrm{C} 1 \mathrm{n}$ (Brunhes) through C22r. The magnetic polarity sequence is interrupted by a sedimentary hiatus at $\sim 270 \mathrm{~m}$ CSF-A based on biostratigraphic constraints. Deeper than 430 m CSF-A, inclinations in Units II-IV, which mainly consist of claystones, exhibit predominantly negative values, indicating a normal polarity. The normal polarity zone spans from $\sim 430$ to 525 $\mathrm{m}$ CSF-A and is assigned to Chron C34n, the CNS, based on shipboard biostratigraphic analysis.

\section{Petrophysics}

Site U1516 physical property data were collected from Holes U1516A, U1516C, and U1516D. Thermal conductivity generally increases to slightly higher values downhole, whereas porosity and $P$ wave velocity show a minor overall decrease downhole. In comparison, bulk and grain density varies very little downhole. Exceptions were observed within the interval between 380 and $460 \mathrm{~m}$ CSF-A, which contains a pronounced excursion toward higher bulk density, thermal conductivity, and $P$-wave velocity values; a minor excursion toward higher grain density values; and a strong excursion to lower porosity values. This interval also corresponds to an interval of relatively high magnetic susceptibility and the top of an interval of increasing NGR (Figure F8). Despite the strong correlation among physical properties, this interval does not correlate to any of the lithostratigraphic unit boundaries. NGR and magnetic susceptibility show similar overall trends throughout Site U1516, increasing when the lithology becomes richer in detrital components. At the transition between lithostratigraphic Units II and III ( 470 m CSFA), both NGR and magnetic susceptibility increase. Enrichment in $\mathrm{U}$ is notable after deconvolution of the NGR in the black claystones possibly related to OAE 2 (Cores 369-U1516C-30R to 32R; 465-470 $\mathrm{m}$ CSF-A). In Unit IV, similar features have been found in the evolution of both proxies with Site U1513, allowing correlations between these two sites.

\section{Geochemistry}

The Site U1516 geochemistry program was designed to characterize the composition of interstitial water and bulk sediments and to assess the potential presence of volatile hydrocarbons for routine safety monitoring. No gas was detected in the 57 headspace gas samples that were taken.

For interstitial water analyses, 52 samples were recovered from whole-round squeezing of samples from Holes U1516A (0-223.6 m CSF-A) and U1516C (244.0-541.6 m CSF-A). Sample salinity is generally constant, with the exception of distinctly fresher interstitial water in lithostratigraphic Unit IV (Figure F8). This low-salinity interval reflects decreased concentrations in many elemental profiles, particularly $\mathrm{Br}^{-}$and $\mathrm{Cl}^{-}$. The $\mathrm{Mg}, \mathrm{K}$, and Ca concentration profiles possibly reflect alteration of volcanic material from depths below the cored interval at this site. The Sr profile likely reflects carbonate diagenesis. Low levels of sulfate reduction were detected; sulfate is present but decreases with depth. Dissolved Si reflects the presence of biogenic opal-A in Subunit Ia; decreasing concentrations deeper than Subunit Ib indicate the opal-A/CT transition. Elevated Mn (Figure F8) and Fe concentrations in parts of Subunits Ia and Ib and Units II-IV demonstrate the reducing character of the sedimentary sequence in these intervals.

A total of 43 bulk sediment samples were collected downhole to $\sim 540$ m CSF-A. Additional samples were measured from the possible OAE 2 interval. $\mathrm{CaCO}_{3}$ content varies from 0 to $94 \mathrm{wt} \%$, reflecting variations in lithology. TOC is $0-1.2 \mathrm{wt} \%$ except in the black shale interval, where it reaches $14 \mathrm{wt} \%$. TN is generally below detection.

Eleven samples, including one from a putative OAE 2 black shale at $\sim 469.5 \mathrm{~m}$ CSF-A, were also analyzed using the source rock analyzer. The sample from the top of the $8 \mathrm{~cm}$ thick black interval indicates Type II kerogen, whereas samples with low ( $<2 \mathrm{wt} \%)$ TOC from the OAE 2 interval and lithostratigraphic Unit IV are composed primarily of Type IV kerogen. $T_{\max }$ values indicate thermal immaturity. 


\section{Stratigraphic correlation}

Cores from Hole U1516A provide a $225 \mathrm{~m}$ thick, continuous record of middle Miocene to recent deposition, and the sequence seems to be biostratigraphically and magnetostratigraphically complete. In Hole U1516C, coring gaps limit knowledge of the lower Miocene, much of the Oligocene, and portions of the Eocene at this site, but both the Oligocene/Miocene boundary interval and a $30 \mathrm{~m}$ long interval of the upper Eocene were well recovered. In addition, much of the Upper Cretaceous, all of the Paleocene, and much of the lower and middle Eocene are either missing or represented in a $15 \mathrm{~m}$ thick interval of condensed deposition and/or erosion and nondeposition spanning from Section 369-U1516C-26R-4, $106 \mathrm{~cm}$, to the top of Core 25R. In contrast, an excellent record of the upper Albian to the middle Turonian was recovered between Holes U1516C and U1516D, including a seemingly complete splice across the possible OAE 2 interval.

\section{Age-depth model and sedimentation rates}

The Neogene has an average sedimentation rate of $\sim 18 \mathrm{~m} / \mathrm{My}$ from the Pleistocene through the upper Miocene (Figure F8). Much of the middle and lower Miocene are missing at a disconformity with an estimated 8 My hiatus. The lowermost Miocene and uppermost Oligocene are present at this site, separated from the lower Oligocene by a disconformity with $\sim 4 \mathrm{My}$ missing. The lower Oligocene through middle Eocene has an average sedimentation rate of $\sim 8 \mathrm{~m} / \mathrm{My}$. This sequence is separated from the Turonian by a condensed interval containing several biostratigraphic units of the middle Paleocene. The lower Paleocene through upper Turonian is missing at a disconformity, with a hiatus of at least 29 My. The middle Turonian through upper Albian has an average sedimentation rate of $\sim 8 \mathrm{~m} / \mathrm{My}$.

\section{Preliminary scientific assessment}

Expedition 369 met all of the proposed science objectives and exceeded many of them during its investigation of the tectonic, paleoclimatic, and paleoceanographic history of the GAB and the Mentelle Basin. Sediment recovered from sites cored in both regions will provide a new perspective on Earth's temperature variation at subpolar latitudes $\left(60^{\circ}-62^{\circ} \mathrm{S}\right)$ during the rise and fall of the mid-Cretaceous and early Eocene hothouse climates, as well as the consequent paleoceanographic and biotic changes. The recovered sediment and basalt will also provide constraints on the timing of rifting and basin subsidence during the last phase of breakup among remnant Gondwana continents.

The following is a discussion of how the scientific objectives of the expedition were met and additional discoveries attained for each of the primary goals:

1. Investigate the timing and causes for the rise and collapse of the Cretaceous hot greenhouse and how this climate shift affected the climate-ocean system and oceanic biota.

Recovery of Cretaceous sediments yielding foraminifers that show minimal diagenetic alteration was a major goal of Expedition 369 because these samples are essential for reliable Cretaceous climate reconstructions. We achieved this objective at Sites U1512U1514 and U1516 (Figures F9, F10, F11, F12). The sequence that will yield the most continuous Cretaceous climate record ranges from the middle Albian through the early Campanian ( 28 My) at Site U1513, adjacent to where Site 258 was drilled with only $22 \%$ Cretaceous sediment recovery (Luyendyk and Davies, 1974). Im-
Figure F9. Age-depth plots constrained by biostratigraphy, Sites U1512U1514 and U1516. Horizontal lines = unconformities.

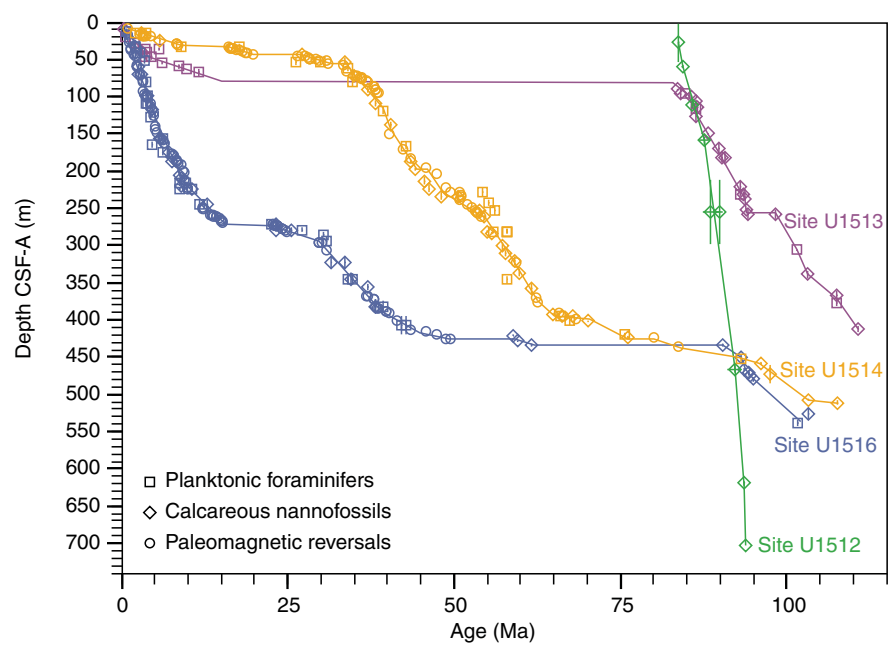

portantly, analysis of Cenomanian sediments yielding good microfossil preservation at Sites U1513, U1514, and U1516 will fill a critical temporal gap in the climate record at southern high latitudes. Moreover, good core recovery and microfossil preservation in portions of the Maastrichtian to Campanian (Site U1514), Santonian to Turonian (Site U1512), Santonian to early Campanian (Site U1513), Turonian to Cenomanian (Sites U1513 and U1516) and late Albian (Sites U1513, U1514, and U1516) (Figures F4, F5, F6, F8) will significantly improve reconstructions of the climatic and oceanographic changes that occurred across the rise and fall of the hot Cretaceous greenhouse climate.

\section{Determine the relative roles of productivity, ocean temperature,} and ocean circulation at high southern latitudes during Cretaceous OAEs.

One of the most important goals of Expedition 369 was to obtain stratigraphically complete and well-preserved sediment records spanning OAEs, including OAE 2 ( 93.8 Ma; Meyers et al., 2012) and OAE 1d ( 100.2 Ma; Erbacher and Thurow, 1997; Bréhéret, 1988, 1997; Leckie et al., 2002). These short-lived (<1 My) episodes of enhanced deposition of organic carbon are associated with carbon isotope excursions and high rates of species turnover (Jenkyns, 1980, 2010; Arthur et al., 1988; Leckie et al., 2002; Jenkyns et al., 2012, 2017). The sediment records cored at Sites U1513, U1514, and U1516 (Figures F10, F11) exceeded our expectations for this objective.

Complete and well-preserved microfossil assemblages were recovered from above, below, and within the likely OAE 2 and $1 \mathrm{~d}$ intervals, and the lithologies include beds of laminated black claystone with high TOC content (Figure F11). Some authors have suggested that OAE 2 , which spans the $\mathrm{C} / \mathrm{T}$ boundary ( 94 Ma), was triggered by $\mathrm{CO}_{2}$ outgassing during a widespread pulse of volcanism (Turgeon and Creaser, 2008; Du Vivier et al., 2014). The 97\% composite recovery across the likely OAE 2 interval in Holes U1513A and U1513D and 100\% recovery in Holes U1516C and U1516D provide a unique opportunity to study this event in greater detail than any OAE 2 sequence in the world because of the abundance and good preservation of calcareous microfossils and the expected presence of organic biomarkers across the interval. Osmium isotope measurements through the cored sequence will determine 
Figure F10. Stratigraphic summary and correlation of NGR records, Sites U1512-U1516 (west to east). Yellow stars = critical intervals that will be the focus of intensive shore-based study. (This figure is also available in an oversized format.)

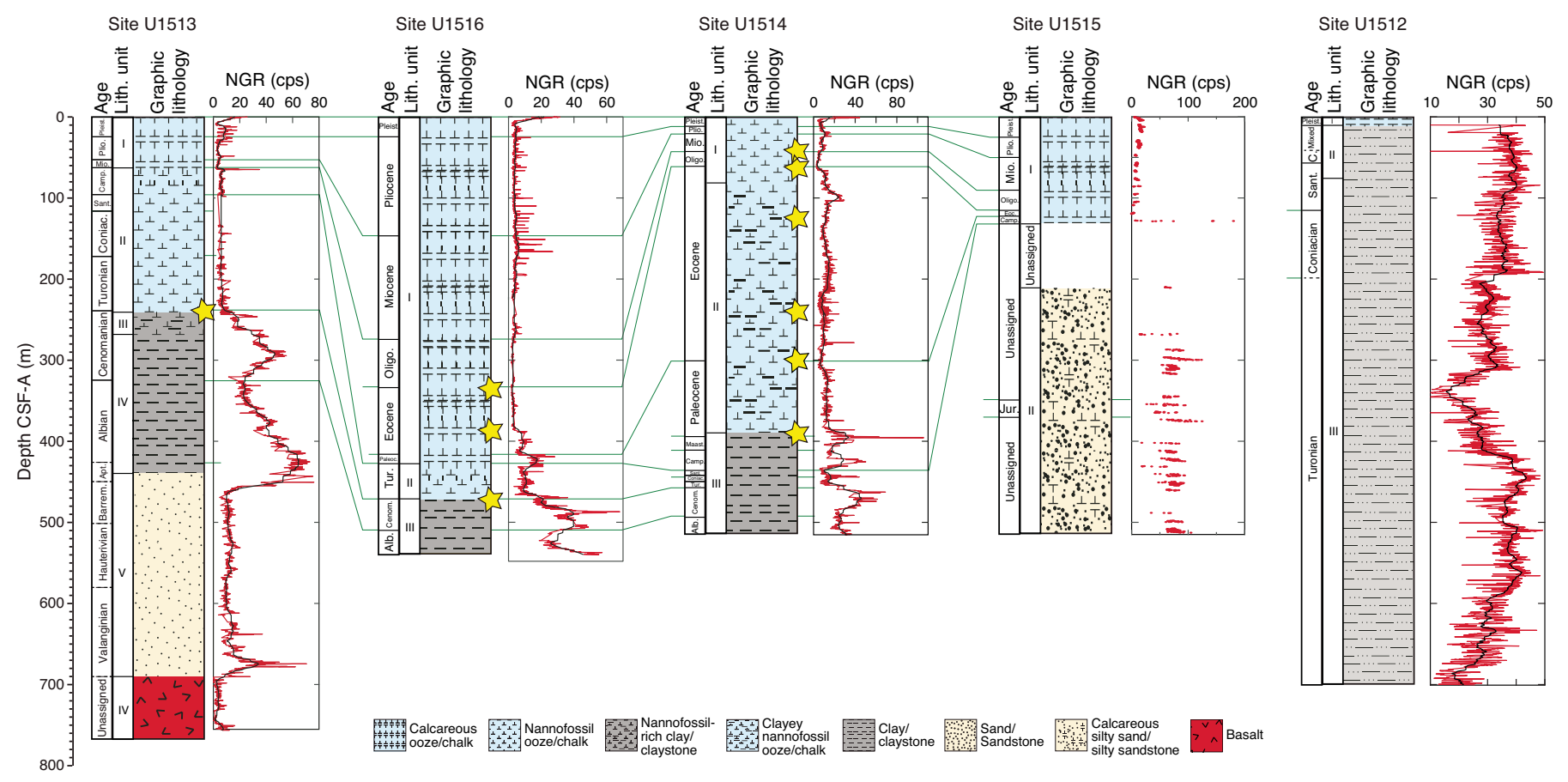

the timing of eruptions prior to, during, and after the event. Parallel oxygen isotope analyses of well-preserved benthic and planktonic foraminifers will provide an important test of whether oceanic warming was triggered by a volcanic event and whether predicted cooling followed the burial of organic carbon during the peak of the OAE (Jenkyns et al., 2017). Measurement of additional chemical proxies and study of the microfossil assemblages for both OAEs will characterize changes in carbon chemistry, nutrient flux, types and amount of organic carbon burial, and changes in microfossil assemblages. Results from study of the OAE intervals cored at Sites U1513, U1514, and U1516 will provide a significant advance in our understanding of the cause and effects of these global anoxic events. A final additional bonus was the apparent recovery at Sites U1513 and U1516 of the relatively little studied Mid-Cenomanian Event.

\section{Identify the main source regions for deep-water and intermediate water masses in the southeast Indian Ocean and how these changed during Gondwana breakup.}

Several intervals cored during Expedition 369 will be investigated using $\varepsilon N d$ to trace sources and circulation patterns of deepwater masses (and thus changing connections between basins), as well as local weathering inputs and potential global influences such as hydrothermal input from large igneous province volcanism. For the Cenomanian in general and the OAE 2 interval in particular, $\varepsilon N d$ patterns obtained from sediments cored at Sites U1513 and U1516 will provide a geographically distant test between competing volcanic and circulation models developed for the North Atlantic. Integration of deep circulation among basins and the increasing importance of the Southern Ocean as a deep-water source can be temporally constrained by comparing $\varepsilon N d$ values and trends in the Mentelle Basin cores to values documented elsewhere. Finally, the timing and regional importance of the opening of the Tasman Gateway and the evolution of Antarctic circulation patterns across the Eocene/Oligocene boundary can be determined from $\varepsilon N d$ values obtained from sediment cores at Site U1514 in the northern Mentelle Basin.

4. Characterize how oceanographic conditions changed at the Mentelle Basin during the Cenozoic opening of the Tasman Gateway and restriction of the Indonesian Gateway.

The opening of the Tasman Gateway and restriction of the Indonesian Gateway were major factors that influenced the evolution of global climate during the Cenozoic, and both oceanic gateway changes profoundly affected the climate of Australia and Antarctica. The Eocene opening of the Drake Passage and the Tasman Gateway led to development of the cold ACC that isolated Antarctica from warm equatorial currents, resulting in the buildup of a continental ice sheet in Antarctica (Bijl et al., 2013; Scher et al., 2006). Northward movement of Australia toward equatorial waters during the Miocene caused substantial reorganization of ocean current pathways in the Indian Ocean and major shifts in the climate of Australia (Gallagher et al., 2017; Groeneveld et al., 2017). Continued northward movement restricted current circulation across the Indonesian Gateway during the Pliocene, which then reduced the influence of the warm-water ITF in the Indian Ocean and initiated the arid climate that characterizes modern western Australia (Christensen et al., 2017).

Because of the mid-latitude location, Cenozoic sedimentation in the Mentelle Basin has been particularly sensitive to northern and southern movements of Antarctic waters and changes in oceanic gateway passages that connect the western equatorial Pacific Ocean with the Indian Ocean. Study of Eocene deposits recovered at Sites U1514 and U1516 (Figure F10) will further our understanding of the oceanographic and climatic consequences of the opening of the Tasman Gateway. An unexpected success with respect to the Paleogene record was the discovery during programmatic XRF core scanning of the recovery of the Paleocene/Eocene Thermal Maximum interval at Site U1514 (Figure F10). 
Figure F11. Bulk sediment geochemical summary, Sites U1512-U1516 (west to east).

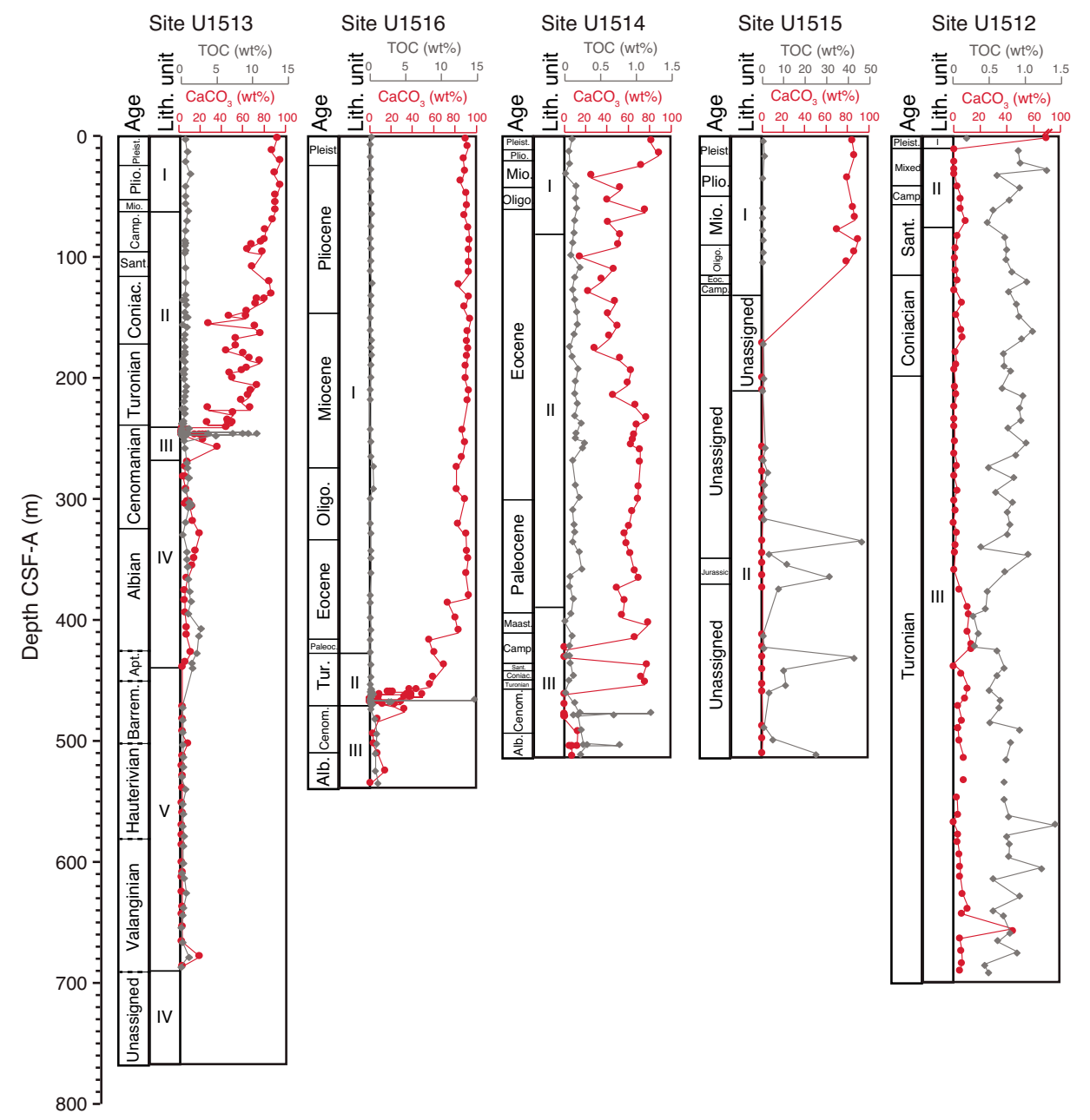

High-resolution studies of Miocene and Pliocene sediments recovered from Sites U1513, U1415, and U1516 will establish the timing, magnitude, and rates of climate and ocean circulation changes that affected the Australian continent and the southeast Indian Ocean region as the seaway between Australia and Antarctica widened and deepened and the Indonesian Gateway became more restricted.

\section{Resolve questions about the volcanic and sedimentary origins of the basin and provide stratigraphic control on the age and nature of the prebreakup succession.}

Sampling the prebreakup sediments was achieved at Site U1515 (Figures F7, F10, F11). The margin-wide unconformity was crossed

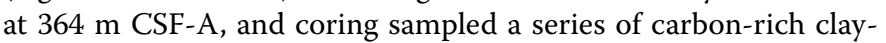
stones interspersed with poorly cemented sandstone in a faultbounded segment of the eastern Mentelle Basin. The claystone is believed to be of Early Jurassic age and to have been deposited during the early stages of rifting within Gondwana, which was undergoing a period of thermal subsidence following an earlier Permian rifting event (Bradshaw et al., 2003). Tilting of these sediments is indicative of a later stage of rifting and fault reactivation in the midto Late Jurassic.

Our deepest hole (U1513E) cored $\sim 84 \mathrm{~m}$ of volcanic material and recovered $\sim 54 \mathrm{~m}$ (Figures F5, F10). Onboard analysis identified separate extrusive flow sequences intercalated with sedimentary breccia beds that were later intruded by a younger diabase dike. The older extrusive volcanics appear to be a mix of subaerial and marine flows, which suggests they were deposited close to sea level. Isotopic dating of the volcanics was not possible on board, although stratigraphic relations mean that the extrusive flows are older than the overlaying mid-Valanginian sediments dated by magnetostratigraphy. Volcanic activity, evidenced from the intersecting seismic profiles as either isolated bright reflectors interpreted as sills or volcanic cones, appears to be present throughout lithostratigraphic Unit V, which is Valanginian to Barremian in age. Although the basalt sequences are highly altered, we anticipate that enough material has been collected for Ar/Ar analysis to at least date some of the flows and the dike. Results will be compared with a recent compilation of basalt samples from both nearby dredge and onland sampling of the Bunbury basalt (Direen et al., 2017; Olierook et al., 2016).

Although only one of the sites in the Mentelle Basin managed to sample the basalt that marks the onset of the breakup between Greater India and Australia/Antarctica, all Expedition 369 sites contribute to significantly improving the stratigraphic control of the regional reflection seismic data. Site U1512 recalibrates the current seismic interpretation and therefore the role of the Wallaroo Fault System as an active fault synchronous with the initial 
Figure F12. Interstitial water geochemical summary, Sites U1512-U1516 (west to east).

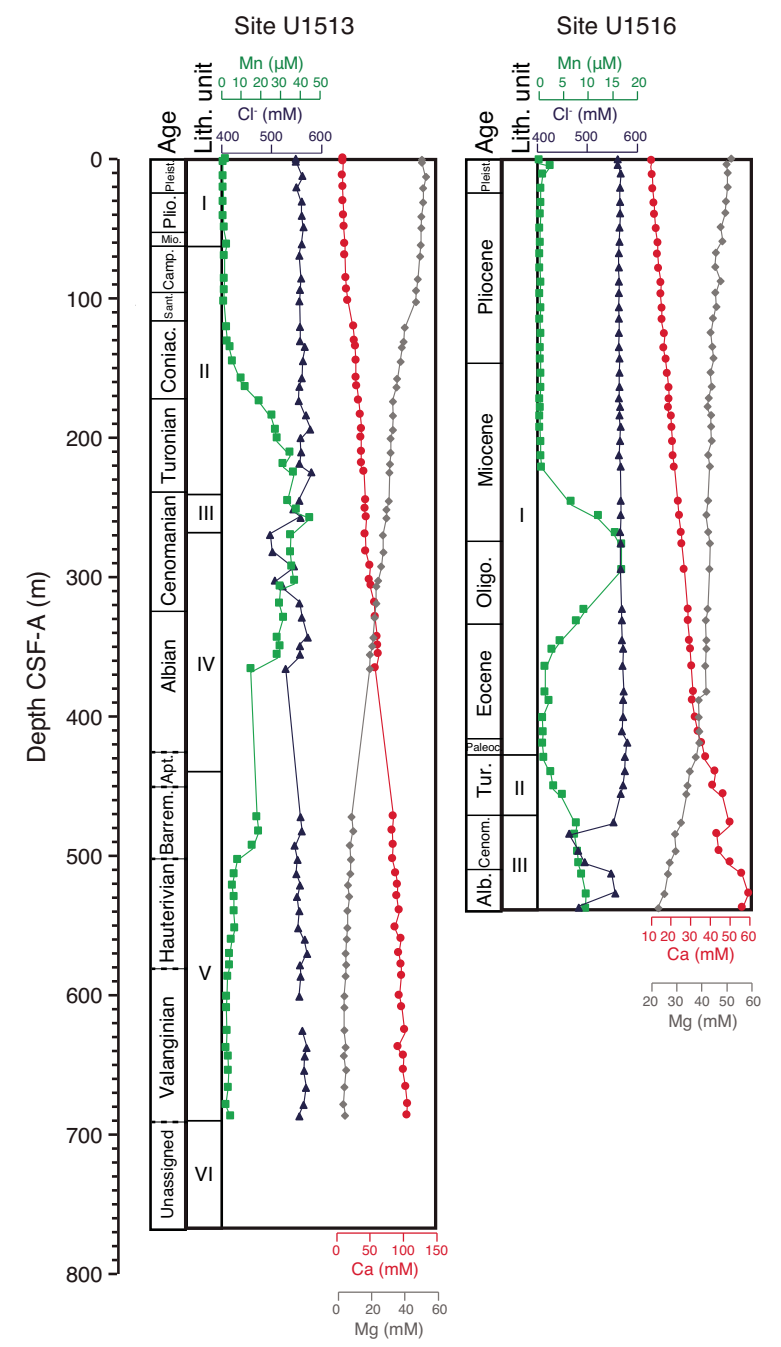

phase of seafloor spreading between Antarctica and Australia. Sediments cored at sites around the Mentelle Basin enable dating of key stratigraphic units that record the rifting of both Greater India and Antarctica from Australia that can be correlated to the regional seismic reflection data. Erosional hiatuses and faults in the sedimentary succession can now be dated and linked with episodes of uplift, erosion, and subsidence, which in turn can be linked to the wider tectonic and thermal histories of this margin.

\section{References}

Ando, A., Huber, B.T., MacLeod, K.G., Ohta, T., and Khim, B.-K., 2009. Blake Nose stable isotopic evidence against the mid-Cenomanian glaciation hypothesis. Geology, 37(5):451-454.

https://doi.org/10.1130/G25580A.1

Ando, A., Kakegawa, T., Takashima, R., and Saito, T., 2002. New perspective on Aptian carbon isotope stratigraphy: data from $\delta^{13} \mathrm{C}$ records of terrestrial organic matter. Geology, 30(3):227-230. https://doi.org/10.1130/0091-

7613(2002)030<0227:NPOACI >2.0.CO;2

Arthur, M.A., Dean, W.E., and Pratt, L.M., 1988. Geochemical and climatic effects of increased marine organic carbon burial at the Cenomanian/Turonian boundary. Nature, 335(6192):714-717. https://doi.org/10.1038/335714a0
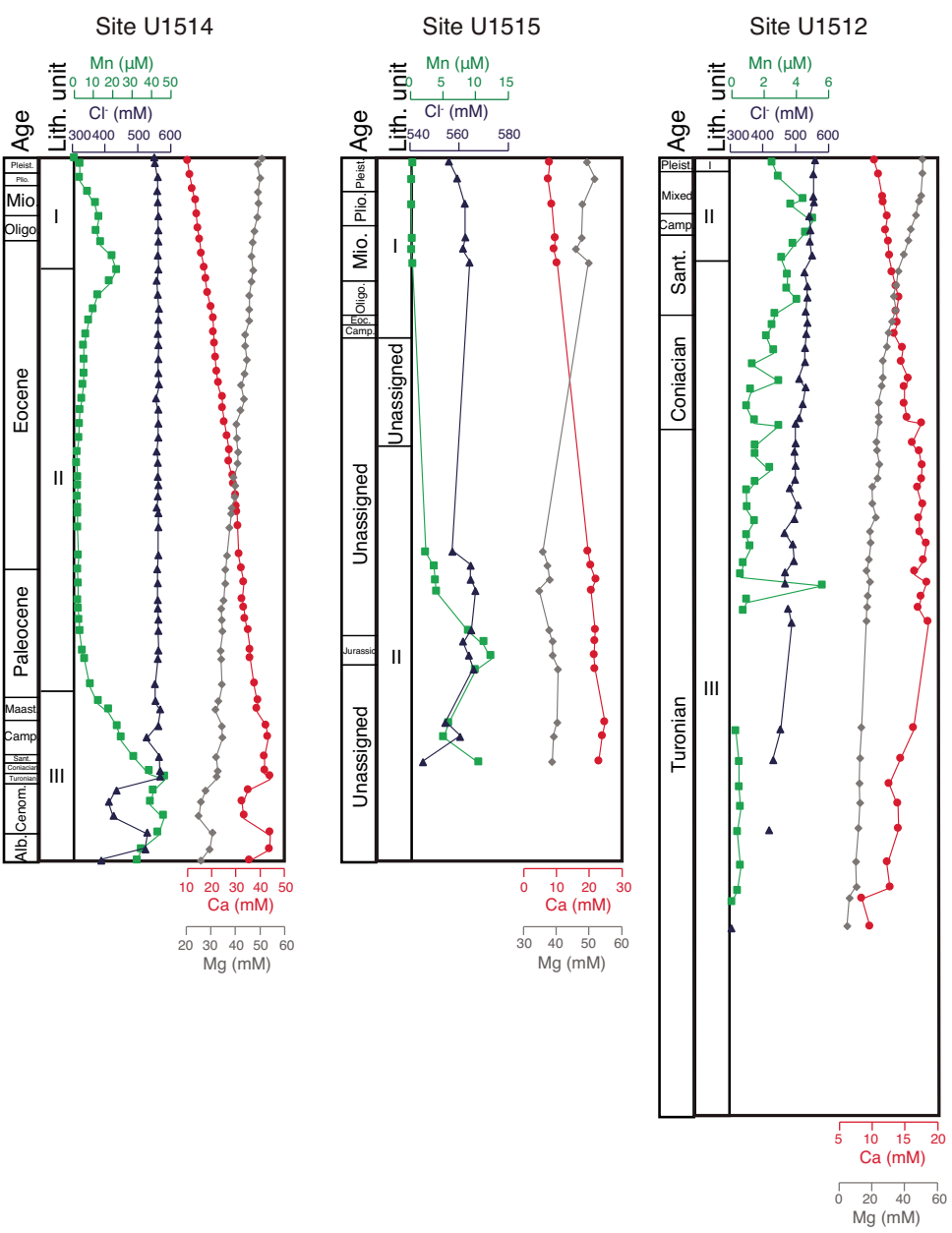

Barrera, E., Savin, S.M., Thomas, E., and Jones, C.E., 1997. Evidence for thermohaline-circulation reversals controlled by sea- level change in the latest Cretaceous. Geology, 25(8):715-718. https://doi.org/10.1130/00917613(1997)025<0715:EFTCRC>2.3.CO;2

Barron, E.J., 1983. A warm, equable Cretaceous: the nature of the problem. Earth-Science Reviews, 19(4):305-338. https://doi.org/10.1016/0012-8252(83)90001-6

Bice, K.L., Huber, B.T., and Norris, R.D., 2003. Extreme polar warmth during the Cretaceous greenhouse? Paradox of the late Turonian $\delta^{18} \mathrm{O}$ record at Deep Sea Drilling Project Site 511. Paleoceanography, 18(2):1031. https://doi.org/10.1029/2002PA000848

Bijl, P.K., Bendle, J.A.P., Bohaty, S.M., Pross, J., Schouten, S., Tauxe, L., Stickley, C.E., McKay, R.M., Röhl, U., Olney, M., Sluijs, A., Escutia, C., Brinkhuis, H., and Expedition 318 Scientists, 2013. Eocene cooling linked to early flow across the Tasmanian Gateway. Proceedings of the National Academy of Sciences of the United States of America, 110(24):9645-9650. https://doi.org/10.1073/pnas.1220872110

Borissova, I., 2002. Geological Framework of the Naturaliste Plateau. Geoscience Australia, 2002/20. http://www.ga.gov.au/metadata-gateway/metadata/record/40535/

Borissova, I., Bradshaw, B.E., Nicholson, C., Struckmeyer, H.I.M., and Payne, D., 2010. New exploration opportunities on the southwest Australian margin: deep-water frontier Mentelle Basin. APPEA Journal, 50:1-13.

Bornemann, A., Norris, R.D., Friedrich, O., Beckmann, B., Schouten, S., Sinninghe Damsté, J.S., Vogel, J., Hofmann, P., and Wagner, T., 2008. Isotopic 
evidence for glaciation during the Cretaceous supergreenhouse. Science, 319(5860):189-192. https://doi.org/10.1126/science.1148777

Borrelli, C., Cramer, B.S., and Katz, M.E., 2014. Bipolar Atlantic deepwater circulation in the middle-late Eocene: effects of Southern Ocean gateway openings. Paleoceanography, 29(4):308-327. https://doi.org/10.1002/2012PA002444

Bowman, V.C., Francis, J.E., Riding, J.B., Hunter, S.J., and Haywood, A.M., 2012. A latest Cretaceous to earliest Paleogene dinoflagellate cyst zonation from Antarctica, and implications for phytoprovincialism in the high southern latitudes. Review of Palaeobotany and Palynology, 171:40-56. https://doi.org/10.1016/j.revpalbo.2011.11.004

Bradshaw, B.E., Rollet, N., Totterdell, J.M., and Borissova, I., 2003. A revised structural framework for frontier basins on the southern and southwestern Australian continental margin. Geoscience Australia, 2003/03. https://d28rz98at9flks.cloudfront.net/42056/Rec2003_003.pdf

Cane, M.A., and Molnar, P., 2001. Closing of the Indonesian Seaway as a precursor to East African aridification around 3-4 million years ago. Nature, 411(6834):157-162. https://doi.org/10.1038/35075500

Christensen, B.A., Renema, W., Henderiks, J., De Vleeschouwer, D., Groeneveld, J., Castañeda, I.S., Reuning, et al., 2017. Indonesian Throughflow drove Australian climate from humid Pliocene to arid Pleistocene. Geophysical Research Letters, 44(13):6914-6925. https://doi.org/10.1002/2017GL072977

Clarke, L.J., and Jenkyns, H.C., 1999. New oxygen isotope evidence for longterm Cretaceous climatic change in the Southern Hemisphere. Geology, 27(8):699-702. https://doi.org/10.1130/0091-

7613(1999)027<0699:NOIEFL >2.3.CO;2

Cramer, B.S., Toggweiler, J.R., Wright, J.D., Katz, M.E., and Miller, K.G., 2009. Ocean overturning since the Late Cretaceous: inferences from a new benthic foraminiferal isotope compilation. Paleoceanography, 24(4). https://doi.org/10.1029/2008PA001683

Direen, N.G., Cohen, B.E., Maas, R., Frey, F.A., Whittaker, J.M., Coffin, M.F., Meffre, S., Halpin, J.A., and Crawford, A.J., 2017. Naturaliste Plateau: constraints on the timing and evolution of the Kerguelen Large Igneous Province and its role in Gondwana breakup. Australian Journal of Earth Sciences, 64(7):851-869.

https://doi.org/10.1080/08120099.2017.1367326

Direen, N.G., Stagg, H.M.J., Symonds, P.A., and Colwell, J.B., 2011. Dominant symmetry of a conjugate southern Australian and East Antarctic magmapoor rifted margin segment. Geochemistry, Geophysics, Geosystems, 12(2):Q02006. https://doi.org/10.1029/2010GC003306

Divakaran, P., and Brassington, G.B., 2011. Arterial ocean circulation of the southeast Indian Ocean. Geophysical Research Letters, 38(1):L01802. https://doi.org/10.1029/2010GL045574

Domingues, C.M., Maltrud, M.E., Wijffels, S.E., Church, J.A., and Tomczak, M., 2007. Simulated Lagrangian pathways between the Leeuwin Current System and the upper-ocean circulation of the southeast Indian Ocean. Deep Sea Research Part II: Topical Studies in Oceanography, 54(810):797-817. https://doi.org/10.1016/j.dsr2.2006.10.003

Du Vivier, A.D.C., Selby, D., Sageman, B.B., Jarvis, I., Gröcke, D.R., and Voigt, S., 2014. Marine ${ }^{187} \mathrm{Os} /{ }^{188} \mathrm{Os}$ isotope stratigraphy reveals the interaction of volcanism and ocean circulation during oceanic anoxic Event 2. Earth and Planetary Science Letters, 389:23-33. https://doi.org/10.1016/j.epsl.2013.12.024

Erbacher, J., and Thurow, J., 1997. Influence of oceanic anoxic events on the evolution of mid-Cretaceous radiolaria in the North Atlantic and western Tethys. Marine Micropaleontology, 30(1-3):139-158. https://doi.org/10.1016/S0377-8398(96)00023-0

Frakes, L.A., Francis, J.E., and Syktus, J.I., 1992. Climate Modes of the Phanerozoic: Cambridge, United Kingdom (Cambridge University Press).

Friedrich, O., Schiebel, R., Wilson, P.A., Weldeab, S., Beer, C.J., Cooper, M.J., and Fiebig, J., 2012. Influence of test size, water depth, and ecology on $\mathrm{Mg} / \mathrm{Ca}, \mathrm{Sr} / \mathrm{Ca}, \delta^{18} \mathrm{O}$ and $\delta^{13} \mathrm{C}$ in nine modern species of planktic foraminifers. Earth and Planetary Science Letters, 319-320:133-145. https://doi.org/10.1016/j.epsl.2011.12.002

Gale, A.S., Hardenbol, J., Hathway, B., Kennedy, W.J., Young, J.R., and Phansalkar, V., 2002. Global correlation of Cenomanian (Upper Cretaceous) sequences: evidence for Milankovitch control on sea level. Geology, 30(4):291-294. https://doi.org/10.1130/0091-

7613(2002)030<0291:GCOCUC >2.0.CO;2

Gallagher, S.J., Fulthorpe, C.S., Bogus, K., Auer, G., Baranwal, S., Castañeda, I.S., Christensen, B.A., De Vleeschouwer, D., Franco, D.R., Groeneveld, J., Gurnis, M., Haller, C., He, Y., Henderiks, J., Himmler, T., Ishiwa, T., Iwatani, H., Jatiningrum, R.S., Kominz, M.A., Korpanty, C.A., Lee, E.Y., Levin, E., Mamo, B.L., McGregor, H.V., McHugh, C.M., Petrick, B.F., Potts, D.C., Lari, A.R., Renema, W., Reuning, L., Takayanagi, H., and Zhang, W., 2017. Expedition 356 summary. In Gallagher, S.J., Fulthorpe, C.S., Bogus, K., and the Expedition 356 Scientists, Indonesian Throughflow. Proceedings of the International Ocean Discovery Program, 356: College Station, TX (International Ocean Discovery Program). https://doi.org/10.14379/iodp.proc.356.101.2017

Gibbons, A.D., Whittaker, J.M., and Müller, R.D., 2013. The breakup of East Gondwana: assimilating constraints from Cretaceous ocean basins around India into a best-fit tectonic model. Journal of Geophysical Research: Solid Earth, 118(3):808-822. https://doi.org/10.1002/jgrb.50079

Godfrey, J.S., 1996. The effect of the Indonesian throughflow on ocean circulation and heat exchange with the atmosphere: a review. Journal of Geophysical Research: Oceans, 101(C5):12217-12237. https://doi.org/10.1029/95JC03860

Gordon, A.L., 1986. Interocean exchange of thermocline water. Journal of Geophysical Research: Oceans, 91(C4):5037-5046. https://doi.org/10.1029/JC091iC04p05037

Gröcke, D.R., Hesselbo, S.P., and Jenkyns, H.C., 1999. Carbon-isotope composition of Lower Cretaceous fossil wood: ocean-atmosphere chemistry and relation to sea-level change. Geology, 27(2):155-158. https://doi.org/10.1130/00917613(1999)027<0155:CICOLC>2.3.CO;2

Groeneveld, J., Henderiks, J., Renema, W., McHugh, C.M., De Vleeschouwer, D., Christensen, B.A., Fulthorpe, C.S., et al., 2017. Australian shelf sediments reveal shifts in Miocene Southern Hemisphere westerlies. Science Advances, 3(5):e1602567. https://doi.org/10.1126/sciadv.1602567

Hay, W.W., 2008. Evolving ideas about the Cretaceous climate and ocean circulation. Cretaceous Research, 29(5-6):725-753. https://doi.org/10.1016/j.cretres.2008.05.025

Hay, W.W., DeConto, R.M., Wold, C.N., Wilson, K.M., Voigt, S., Schulz, M., Rossby Wold, A., Dullo, W.-C., Ronov, A.B., Balukhovsky, A.N., and Söding, E., 1999. Alternative global Cretaceous paleogeography. In Barrera, E., and Johnson, C.C. (Eds.), Evolution of the Cretaceous Ocean-Climate System. Special Paper - Geological Society of America, 332:1-47. https://doi.org/10.1130/0-8137-2332-9.1

Hollis, C.J., Taylor, K.W.R., Handley, L., Pancost, R.D., Huber, M., Creech, J.B., Hines, B.R., Crouch, E.M., Morgans, H.E.G., Crampton, J.S., Gibbs, S., Pearson, P.N., and Zachos, J.C., 2012. Early Paleogene temperature history of the Southwest Pacific Ocean: reconciling proxies and models. Earth and Planetary Science Letters, 349-350:53-66. https://doi.org/10.1016/j.epsl.2012.06.024

Huber, B.T., Hobbs, R.W., Bogus, K.A., Batenburg, S.J., Brumsack, H.-J., do Monte Guerra, R., Edgar, K.M., Edvardsen, T., Garcia Tejada, M.L., Harry, D.L., Hasegawa, T., Haynes, S.J., Jiang, T., Jones, M.M., Kuroda, J., Lee, E.Y., Li, Y.-X., MacLeod, K.G., Maritati, A., Martinez, M., O'Connor, L.K., Petrizzo, M.R., Quan, T.M., Richter, C., Riquier, L., Tagliaro, G.T., Wainman, C.C., Watkins, D.K., White, L.T., Wolfgring, E., and Xu, Z., 2019a. Site U1512. In Hobbs, R.W., Huber, B.T., Bogus, K.A., and the Expedition 369 Scientists, Australia Cretaceous Climate and Tectonics. Proceedings of the International Ocean Discovery Program, 369: College Station, TX (International Ocean Discovery Program). https://doi.org/10.14379/iodp.proc.369.103.2019

Huber, B.T., Hobbs, R.W., Bogus, K.A., Batenburg, S.J., Brumsack, H.-J., do Monte Guerra, R., Edgar, K.M., Edvardsen, T., Garcia Tejada, M.L., Harry, D.L., Hasegawa, T., Haynes, S.J., Jiang, T., Jones, M.M., Kuroda, J., Lee, E.Y., Li, Y.-X., MacLeod, K.G., Maritati, A., Martinez, M., O'Connor, L.K., Petrizzo, M.R., Quan, T.M., Richter, C., Riquier, L., Tagliaro, G.T., Wainman, C.C., Watkins, D.K., White, L.T., Wolfgring, E., and Xu, Z., $2019 \mathrm{~b}$. 
Site U1513. In Hobbs, R.W., Huber, B.T., Bogus, K.A., and the Expedition 369 Scientists, Australia Cretaceous Climate and Tectonics. Proceedings of the International Ocean Discovery Program, 369: College Station, TX (International Ocean Discovery Program). https://doi.org/10.14379/iodp.proc.369.104.2019

Huber, B.T., Hobbs, R.W., Bogus, K.A., Batenburg, S.J., Brumsack, H.-J., do Monte Guerra, R., Edgar, K.M., Edvardsen, T., Garcia Tejada, M.L., Harry, D.L., Hasegawa, T., Haynes, S.J., Jiang, T., Jones, M.M., Kuroda, J., Lee, E.Y., Li, Y.-X., MacLeod, K.G., Maritati, A., Martinez, M., O'Connor, L.K., Petrizzo, M.R., Quan, T.M., Richter, C., Riquier, L., Tagliaro, G.T., Wainman, C.C., Watkins, D.K., White, L.T., Wolfgring, E., and Xu, Z., 2019c. Site U1514. In Hobbs, R.W., Huber, B.T., Bogus, K.A., and the Expedition 369 Scientists, Australia Cretaceous Climate and Tectonics. Proceedings of the International Ocean Discovery Program, 369: College Station, TX (International Ocean Discovery Program). https://doi.org/10.14379/iodp.proc.369.105.2019

Huber, B.T., Hobbs, R.W., Bogus, K.A., Batenburg, S.J., Brumsack, H.-J., do Monte Guerra, R., Edgar, K.M., Edvardsen, T., Garcia Tejada, M.L., Harry, D.L., Hasegawa, T., Haynes, S.J., Jiang, T., Jones, M.M., Kuroda, J., Lee, E.Y., Li, Y.-X., MacLeod, K.G., Maritati, A., Martinez, M., O'Connor, L.K., Petrizzo, M.R., Quan, T.M., Richter, C., Riquier, L., Tagliaro, G.T., Wainman, C.C., Watkins, D.K., White, L.T., Wolfgring, E., and Xu, Z., 2019d. Site U1515. In Hobbs, R.W., Huber, B.T., Bogus, K.A., and the Expedition 369 Scientists, Australia Cretaceous Climate and Tectonics. Proceedings of the International Ocean Discovery Program, 369: College Station, TX (International Ocean Discovery Program).

https://doi.org/10.14379/iodp.proc.369.106.2019

Huber, B.T., Hobbs, R.W., Bogus, K.A., Batenburg, S.J., Brumsack, H.-J., do Monte Guerra, R., Edgar, K.M., Edvardsen, T., Garcia Tejada, M.L., Harry, D.L., Hasegawa, T., Haynes, S.J., Jiang, T., Jones, M.M., Kuroda, J., Lee, E.Y., Li, Y.-X., MacLeod, K.G., Maritati, A., Martinez, M., O'Connor, L.K., Petrizzo, M.R., Quan, T.M., Richter, C., Riquier, L., Tagliaro, G.T., Wainman, C.C., Watkins, D.K., White, L.T., Wolfgring, E., and Xu, Z., 2019e. Site U1516. In Hobbs, R.W., Huber, B.T., Bogus, K.A., and the Expedition 369 Scientists, Australia Cretaceous Climate and Tectonics. Proceedings of the International Ocean Discovery Program, 369: College Station, TX (International Ocean Discovery Program). https://doi.org/10.14379/iodp.proc.369.107.2019

Huber, B.T., Hodell, D.A., and Hamilton, C.P., 1995. Mid- to Late Cretaceous climate of the southern high latitudes: stable isotopic evidence for minimal equator-to-pole thermal gradients. Geological Society of America Bulletin, 107(10):1164-1191. https://doi.org/10.1130/0016-7606(1995)107<1164:MLC$\mathrm{COT}>2.3 . \mathrm{CO} ; 2$

Huber, B.T., MacLeod, K.G., Gröcke, D.R., and Kucera, M., 2011. Paleotemperature and paleosalinity inferences and chemostratigraphy across the Aptian/Albian boundary in the subtropical North Atlantic. Paleoceanography, 26(4). https://doi.org/10.1029/2011PA002178

Huber, B.T., MacLeod, K.G., Watkins, D.K., and Coffin, M.F., 2018. The rise and fall of the Cretaceous Hot Greenhouse climate. Global and Planetary Change, 167:1-23. https://doi.org/10.1016/j.gloplacha.2018.04.004

Huber, B.T., Norris, R.D., and MacLeod, K.G., 2002. Deep sea paleotemperature record of extreme warmth during the Cretaceous. Geology, 30(2):123-126. https://doi.org/10.1130/00917613(2002)030<0123:DSPROE >2.0.CO;2

Huber, M., Brinkhuis, H., Stickley, C.E., Döös, K., Sluijs, A., Warnaar, J., Schellenberg, S.A., and Williams, G.L., 2004. Eocene circulation of the Southern Ocean: was Antarctica kept warm by subtropical waters? Paleoceanography, 19(4):PA4026. https://doi.org/10.1029/2004PA001014

Jahren, A.H., Arens, N.C., Sarmiento, G., Guerrero, J., and Amundson, R., 2001. Terrestrial record of methane hydrate dissociation in the Early Cretaceous. Geology, 29(2):159-162. https://doi.org/10.1130/0091-7613(2001)029<0159:TROMHD>2.0.CO;2

Jarvis, I., Gale, A.S., Jenkyns, H.C., and Pearce, M.A., 2006. Secular variation in Late Cretaceous carbon isotopes: a new $\delta^{13} \mathrm{C}$ carbonate reference curve for the Cenomanian-Campanian (99.6-70.6 Ma). Geological Magazine, 143(5):561-608. https://doi.org/10.1017/S0016756806002421
Jenkyns, H.C., 1980. Cretaceous anoxic events: from continents to oceans. Journal of the Geological Society, 137(2):171-188. https://doi.org/10.1144/gsjgs.137.2.0171

Jenkyns, H.C., 2010. Geochemistry of oceanic anoxic events. Geochemistry, Geophysics, Geosystems, 11(3):Q03004. https://doi.org/10.1029/2009GC002788

Jenkyns, H.C., Dickson, A.J., Ruhl, M., and van den Boorn, S.H.J.M., 2017. Basalt-seawater interaction, the Plenus Cold Event, enhanced weathering and geochemical change: deconstructing oceanic anoxic Event 2 (Cenomanian-Turonian, Late Cretaceous). Sedimentology, 64(1):16-43. https://doi.org/10.1111/sed.12305

Jenkyns, H.C., Schouten-Huibers, L., Schouten, S., and Sinninghe Damsté, J.S., 2012. Warm Middle Jurassic-Early Cretaceous high-latitude sea-surface temperatures from the Southern Ocean. Climate of the Past, 8(1):215-226. https://doi.org/10.5194/cp-8-215-2012

Jiménez Berrocoso, Á., MacLeod, K.G., Huber, B.T., Lees, J.A., Wendler, I., Bown, P.R., Mweneinda, A.K., Isaza Londoño, C., and Singano, J.M., 2010. Lithostratigraphy, biostratigraphy and chemostratigraphy of Upper Cretaceous sediments from southern Tanzania: Tanzania Drilling Project Sites 21-26. Journal of African Earth Sciences, 57(1-2):47-69. https://doi.org/10.1016/j.jafrearsci.2009.07.010

Jung, C., Voigt, S., Friedrich, O., Koch, M.C., and Frank, M., 2013. Campanian-Maastrichtian ocean circulation in the tropical Pacific. Paleoceanography, 28(3):562-573. https://doi.org/10.1002/palo.20051

Karas, C., Nürnberg, D., Gupta, A.K., Tiedemann, R., Mohan, K., and Bickert, T., 2009. Mid-Pliocene climate change amplified by a switch in Indonesian subsurface throughflow. Nature Geoscience, 2(6):434-438. https://doi.org/10.1038/ngeo520

Kuhnt, W., Holbourn, A., Hall, R., Zuvela, M., and Käse, R., 2004. Neogene history of the Indonesian Throughflow. In Clift, P., Wang, P., Kuhnt, W., and Hayes, D. (Eds.), Continent-Ocean Interactions within East Asian Marginal Seas. Geophysical Monograph, 149:299-320. https://doi.org/10.1029/149GM16

Leckie, R.M., Bralower, T.J., and Cashman, R., 2002. Oceanic anoxic events and plankton evolution: biotic response to tectonic forcing during the mid-Cretaceous. Paleoceanography, 17(3):1041. https://doi.org/10.1029/2001PA000623

Lee, T., Fukumori, I., Menemenlis, D., Xing, Z., and Fu, L.-L., 2002. Effects of the Indonesian throughflow on the Pacific and Indian Oceans. Journal of Physical Oceanography, 32(5):1404-1429.

https://doi.org/10.1175/15200485(2002)032<1404:EOTITO >2.0.CO;2

Lumpkin, R., and Speer, K., 2007. Global ocean meridional overturning. Journal of Physical Oceanography, 37(10):2550-2562. https://doi.org/10.1175/JPO3130.1

MacLeod, K.G., Huber, B.T., Jiménez Berrocoso, Á., and Wendler, I., 2013. A stable and hot Turonian without glacial $\delta^{18} \mathrm{O}$ excursions is indicated by exquisitely preserved Tanzanian foraminifera. Geology, 41(10):10831086. https://doi.org/10.1130/G34510.1

MacLeod, K.G., Londoño, C.I., Martin, E.E., Jiménez Berrocoso, Á., and Basak, C., 2011. Changes in North Atlantic circulation at the end of the Cretaceous greenhouse interval. Nature Geoscience, 4(11):779-782. https://doi.org/10.1038/ngeo1284

MacLeod, K.G., Martin, E.E., and Blair, S.W., 2008. Nd isotopic excursion across Cretaceous Oceanic Anoxic Event 2 (Cenomanian-Turonian) in the tropical North Atlantic. Geology, 36(10):811-814. https://doi.org/10.1130/G24999A.1

Maloney, D., Sargent, C., Direen, N.G., Hobbs, R.W., and Gröcke, D.R., 2011. Re-evaluation of the Mentelle Basin, a polyphase rifted margin basin, offshore southwest Australia: new insights from integrated regional seismic datasets. Solid Earth, 2(2):107-123.

https://doi.org/10.5194/se-2-107-2011

Maritati, A., Aitken, A.R.A., Young, D.A., Roberts, J.L., Blankenship, D.D., and Siegert, M.J., 2016. The tectonic development and erosion of the Knox Subglacial Sedimentary Basin, East Antarctica. Geophysical Research Letters, 43(20):10,728-10,737. https://doi.org/10.1002/2016GL071063

Martin, E.E., MacLeod, K.G., Jiménez Berrocoso, A., and Bourbon, E., 2012. Water mass circulation on Demerara Rise during the Late Cretaceous 
based on Nd isotopes. Earth and Planetary Science Letters, 327-328:111120. https://doi.org/10.1016/j.epsl.2012.01.037

Martin, E.E., and Scher, H.D., 2004. Preservation of seawater Sr and Nd isotopes in fossil fish teeth: bad news and good news. Earth and Planetary Science Letters, 220(1-2):25-39. https://doi.org/10.1016/S0012-821X(04)00030-5

McCartney, M.S., and Donohue, K.A., 2007. A deep cyclonic gyre in the Australian-Antarctic Basin. Progress in Oceanography, 75(4):675-750. https://doi.org/10.1016/j.pocean.2007.02.008

Meuleners, M.J., Pattiaratchi, C.B., and Ivey, G.N., 2007. Numerical modelling of the mean flow characteristics of the Leeuwin Current System. Deep Sea Research Part II: Topical Studies in Oceanography, 54(8-10):837-858. https://doi.org/10.1016/j.dsr2.2007.02.003

Meyers, S.R., Siewert, S.E., Singer, B.S., Sageman, B.B., Condon, D.J., Obradovich, J.D., Jicha, B.R., and Sawyer, D.A., 2012. Intercalibration of radioisotopic and astrochronologic time scales for the Cenomanian-Turonian boundary interval, Western Interior Basin, USA. Geology, 40(1):7-10. http://dx.doi.org/10.1130/G32261.1

Middleton, J.F., and Cirano, M., 2002. A northern boundary current along Australia's southern shelves: the Flinders Current. Journal of Geophysical Research: Oceans, 107(C9):3129. https://doi.org/10.1029/2000JC000701

Miller, K.G., Barrera, E., Olsson, R.K., Sugarman, P. J., and Savin, S.M., 1999. Does ice drive early Maastrichtian eustasy? Geology, 27(9):783-786. https://doi.org/10.1130/00917613(1999)027<0783:DIDEME >2.3.CO;2

Miller, K.G., Kominz, M.A., Browning, J.V., Wright, J.D., Mountain, G.S., Katz, M.E., Sugarman, P.J., Cramer, B.S., Christie-Blick, N., and Pekar, S.F., 2005. The Phanerozoic record of global sea-level change. Science, 310(5752):1293-1298. https://doi.org/10.1126/science.1116412

Moiroud M., Pucéat, E., Donnadieu, Y., Bayon, G., Moriya, K., Deconinck, J.F., and Boyet, M., 2013. Evolution of the neodymium isotopic signature of neritic seawater on a northwestern Pacific margin: new constrains on possible end-members for the composition of deep-water masses in the Late Cretaceous ocean. Chemical Geology, 356:160-170. https://doi.org/10.1016/j.chemgeo.2013.08.008

Moriya, K., Wilson, P.A., Friedrich, O., Erbacher, J., and Kawahata, H., 2007. Testing for ice sheets during the mid-Cretaceous greenhouse using glassy foraminiferal calcite from the mid-Cenomanian tropics on Demerara rise. Geology, 35(7):615-618. https://doi.org/10.1130/G23589A.1

Müller, R.D., Gaina, C., and Clarke, S., 2000. Seafloor spreading around Australia. In Veevers, J.J. (Ed.), Billion-Year Earth History of Australia and Neighbours in Gondwanaland: Sydney (GEMOC Press), 18-28.

Murphy, D.P., and Thomas, D.J., 2012. Cretaceous deep-water formation in the Indian sector of the Southern Ocean. Paleoceanography, 27(1). https://doi.org/10.1029/2011PA002198

O'Brien, C.L., Robinson, S.A., Pancost, R.D., Sinninghe Damsté, J.S., Schoulten, S., Lunt, D.J., Alsenz, H., Bornemann, A., Bottini, C., Brassell, S.C., Farnsworth, A., Forster, A., Huber, B.T., Inglis, G.N., Jenkyns, H.C., Linnert, C., Littler, K., Markwick, P., McAnena, A., Mutterlose, J., Naafs, B.D.A., Püttmann, W., Sluijs, A., van Helmond, N.A.G.M., Vellekoop, J., Wagner, T., and Wrobel, N.E., 2017. Cretaceous sea-surface temperature evolution: constraints from $\mathrm{TEX}_{86}$ and planktonic foraminiferal oxygen isotopes. Earth-Science Reviews, 172:224-247. https://doi.org/10.1016/j.earscirev.2017.07.012

Olierook, H.K.H., Jourdan, F., Merle, R.E., Timms, N.E., Kusznir, N., and Muhling, J.R., 2016. Bunbury basalt: Gondwana breakup products or earliest vestiges of the Kerguelen mantle plume? Earth and Planetary Science Letters, 440:20-32. https://doi.org/10.1016/j.epsl.2016.02.008

Pattiaratchi, C., 2006. Surface and sub-surface circulation and water masses off Western Australia. Bulletin of the Australian Meteorological and Oceanographic Society, 19:95-104.

Petkovic, P., 1975. Naturaliste Plateau. In Veevers, J.J. (Ed.), Deep Sea Drilling in Australasian Waters: North Ryde, N.S.W., Australia (Macquarie University), 24-25.
Ridgway, K.R., and Dunn, J.R., 2007. Observational evidence for a Southern Hemisphere oceanic supergyre. Geophysical Research Letters, 34(13):L13612. https://doi.org/10.1029/2007GL030392

Robinson, S.A., Murphy, D.P., Vance, D., and Thomas, D.J., 2010. Formation of "Southern Component Water" in the Late Cretaceous: evidence from Ndisotopes. Geology, 38(10):871-874. https://doi.org/10.1130/G31165.1

Robinson, S.A., and Vance, D., 2012. Widespread and synchronous change in deep-ocean circulation in the North and South Atlantic during the Late Cretaceous. Paleoceanography, 27(1):PA1102. https://doi.org/10.1029/2011PA002240

Scher, H.D., and Martin, E.E., 2006. Timing and climatic consequences of the opening of Drake Passage. Science, 312(5772):428-430. https://doi.org/10.1126/science.1120044

Schlanger, S.O., and Jenkyns, H.C., 1976. Cretaceous oceanic anoxic events: causes and consequences. Geologie en Mijnbouw, 55:179-184.

Sloyan, B.M., 2006. Antarctic bottom and lower circumpolar deep water circulation in the eastern Indian Ocean. Journal of Geophysical Research: Oceans, 111(C2):C02006. https://doi.org/10.1029/2005JC003011

Speich, S., Blanke, B., and Cai, W., 2007. Atlantic meridional overturning circulation and the Southern Hemisphere supergyre. Geophysical Research Letters, 34(23):L23614. https://doi.org/10.1029/2007GL031583

Speich, S., Blanke, B., de Vries, P., Drijfhout, S., Döös, K., Ganachaud, A., and Marsh, R., 2002. Tasman leakage: a new route in the global ocean conveyor belt. Geophysical Research Letters, 29(10):55-1-55-4. https://doi.org/10.1029/2001GL014586

Stoll, H.M., and Schrag, D.P., 2000. High resolution stable isotope records from the upper Cretaceous of Italy and Spain: glacial episodes in a greenhouse planet? Geological Society of America Bulletin, 112(2):308-319. https://doi.org/10.1130/0016-7606(2000)112<0308:HRSIRF>2.3.CO;2

Totterdell, J.M., Blevin, J.E., Struckmeyer, H.I.M., Bradshaw, B.E., Colwell, J.B., and Kennard, J.M., 2000. A new stratigraphic framework for the Great Australian Bight: starting with a clean slate. APPEA Journal, 40:95-117.

Totterdell, J.M., Struckmeyer, H.I.M., Boreham, C.J., Mitchell, C.H., Monteil, E., and Bradshaw, B.E., 2008. Mid-Late Cretaceous organic-rich rocks from the eastern Bight Basin: implications for prospectivity. In Blevin, J.E., Bradshaw, B.E., and Uruski, C. (Eds.), Eastern Australasian Basins Symposium III. Petroleum Exploration Society of Australia Special Publication, 137-158.

Turgeon, S.C., and Creaser, R.A., 2008. Cretaceous oceanic anoxic Event 2 triggered by a massive magmatic episode. Nature, 454(7202):323-326. https://doi.org/10.1038/nature07076

van Sebille, E., England, M.H., Zika, J.D., and Sloyan, B.M., 2012. Tasman leakage in a fine-resolution ocean model. Geophysical Research Letters, 39(6):L06601. https://doi.org/10.1029/2012GL051004

Veevers, J.J., 2006. Updated Gondwana (Permian-Cretaceous) earth history of Australia. Gondwana Research, 9(3):231-260. https://doi.org/10.1016/j.gr.2005.11.005

Voigt, S., Jung, C., Friedrich, O., Frank, M., Teschner, C., and Hoffmann, J., 2013. Tectonically restricted deep-ocean circulation at the end of the Cretaceous greenhouse. Earth and Planetary Science Letters, 369-370:169177. https://doi.org/10.1016/j.epsl.2013.03.019

Waite, A.M., Thompson, P.A., Pesant, S., Feng, M., Beckley, L.E., Domingues, C.M., Gaughan, D., Hanson, C.E., Holl, C.M., Koslow, T., Meuleners, M., Montoya, J.P., Moore, T., Muhling, B.A., Paterson, H., Rennie, S., Strzelecki, J., and Twomey, L., 2007. The Leeuwin Current and its eddies: an introductory overview. Deep Sea Research Part II: Topical Studies in Oceanography, 54(8-10):789-796. https://doi.org/10.1016/j.dsr2.2006.12.008

White, L.T., Gibson, G.M., and Lister, G.S., 2013. A reassessment of paleogeographic reconstructions of eastern Gondwana: bringing geology back into the equation. Gondwana Research, 24(3-4):984-998. https://doi.org/10.1016/j.gr.2013.06.009

Zheng, X.-Y., Jenkyns, H.C., Gale, A.S., Ward, D.J., and Henderson, G.M., 2013. Changing ocean circulation and hydrothermal inputs during oceanic anoxic Event 2 (Cenomanian-Turonian): evidence from Nd-isotopes in the European shelf sea. Earth and Planetary Science Letters, 375:338348. https://doi.org/10.1016/j.epsl.2013.05.053 